IZA DP No. 1149

Identity and Racial Harassment

Heather Antecol

Deborah A. Cobb-Clark

May 2004 


\title{
Identity and Racial Harassment
}

\author{
Heather Antecol \\ Claremont McKenna College \\ Deborah A. Cobb-Clark \\ SPEAR, RSSS, Australian National University \\ and IZA Bonn
}

Discussion Paper No. 1149

May 2004

IZA

P.O. Box 7240

53072 Bonn

Germany

Phone: +49-228-3894-0

Fax: +49-228-3894-180

Email: iza@iza.org

\begin{abstract}
Any opinions expressed here are those of the author(s) and not those of the institute. Research disseminated by IZA may include views on policy, but the institute itself takes no institutional policy positions.

The Institute for the Study of Labor (IZA) in Bonn is a local and virtual international research center and a place of communication between science, politics and business. IZA is an independent nonprofit company supported by Deutsche Post World Net. The center is associated with the University of Bonn and offers a stimulating research environment through its research networks, research support, and visitors and doctoral programs. IZA engages in (i) original and internationally competitive research in all fields of labor economics, (ii) development of policy concepts, and (iii) dissemination of research results and concepts to the interested public.
\end{abstract}

IZA Discussion Papers often represent preliminary work and are circulated to encourage discussion. Citation of such a paper should account for its provisional character. A revised version may be available on the IZA website (www.iza.org) or directly from the author. 
IZA Discussion Paper No. 1149

May 2004

\section{ABSTRACT}

\section{Identity and Racial Harassment ${ }^{*}$}

In a 1996 survey of U.S. military personnel, more than 65 percent experienced racially offensive behavior, and approximately one-in-ten reported threatening incidents or careerrelated racial discrimination. Perceived racial harassment is driven by social classifications that extend beyond racial group membership. While race clearly matters, there is also diversity in the harassment experiences of individuals of the same race with diverging organizational, cultural or social experiences. Social prescriptions constraining inter-racial interactions are associated with higher rates of offensive racial encounters and more careerrelated discrimination, while aspects of an installation's institutional culture also directly affect harassment. Together, these results lend support for a model of racial harassment that encompasses both institutional factors and a multifaceted notion of racial identity.

JEL Classification: J15, J70, J81

Keywords: $\quad$ harassment, identity, U.S. military

Corresponding author:

Deborah Cobb-Clark

SPEAR Centre, RSSS, BId. 9

Australian National University

Canberra ACT, 0200

Australia

Email: dcclark@coombs.anu.edu.au

\footnotetext{
* We thank the Defense Manpower Data Center for providing us access to variables related to location from the confidential files of the 1996 Armed Forces Equal Opportunity Survey (AF-EOS).
} 


\section{"No one knows precisely how identities are forged, but it is safe to say that identities are not invented: an identity would seem to be arrived at by the way in which the person faces and uses his experience. It is a long drawn-out and somewhat bewildering and awkward process."}

James Baldwin 1972

\section{Introduction}

Economists have recently become more interested in the ways in which an individual's identity might influence economic behavior. Though notions of identity differ, it is generally the case that identity is seen to have gender, racial, cultural and social dimensions. ${ }^{1}$ Identification with particular groups in society opens the door for individual behavior and subsequent outcomes to be influenced by social norms, customs, or expectations. Consequently, incorporating identity into economic analyses allows us to account for a range of phenomenon - e.g., behavior that seems detrimental—-that standard economic models cannot (Jones, 1984; Bernheim, 1994; Akerlof, 1997; Akerlof and Kranton, 2000). Identity itself is inherently endogenous, reflecting the outcome of fundamental economic decisions. Frijters (1998), for example, argues that group identities form as groups compete over scarce resources, while in a similar vein Darity et. al. (2002) model racial identity as a form of capital asset or economic property. Identities may also form as individuals make choices about the attributes (e.g., mannerisms, modes of speech or clothing) that others will use in categorizing them (Fryer and Jackson, 2003).

One of the ways in which economic models of identity may ultimately prove most useful is in expanding our understanding of labor market discrimination. Identity theory

\footnotetext{
${ }^{1}$ The American Heritage Dictionary (1980) defines identity to be "the behavioral or personal characteristics by which an individual is recognizable as a member of a group”. Fryer and Jackson (2003) define "identity" to be a set of personal attributes, while Akerlof and Kranton (2000) see it simply as "a person's sense of self".
} 
adds a new dimension to existing theoretical explanations of discrimination. Becker's (1971) classic "taste for discrimination" model, for example, might be reinterpreted as a "loss of identity model" (see Akerlof and Kranton, 2000). At the same time, an endogenous process of identification resulting from the use of social categories to process information about interactions with outside groups (Fryer and Jackson, 2003) or motivated by property rights over scarce resources (Frijters, 1998; Darity, et al., 2002; Bodenhorn and Ruebeck, 2003) provide alternative explanations for discrimination. ${ }^{2}$

Empirical estimates of labor market discrimination are generally derived as the residual difference in the aggregate outcomes of different groups that remains once observable productivity-related characteristics have been taken into account. It is well known, however, that omitted variables, unobserved heterogeneity, and measurement error will all confound residual-based estimates of labor market discrimination. This has led to an increased interest in using alternative strategies-including direct, survey evidence - to measure discrimination (e.g., Kuhn, 1987; Hampton and Heywood, 1993; Laband and Lentz 1998; Hallock, et. al, 1998; Johnson and Neumark, 1997; Antecol and Kuhn, 2000; Shields and Wheatly Price, 2002a, 2002b; Antecol and Cobb-Clark, 2001, 2004a). ${ }^{3}$ We believe that it is in the interpretation of these measures of discrimination where the utility of identity theory is likely to be the greatest.

\footnotetext{
${ }^{2}$ Unlike the "taste for" and statistical discrimination models, these latter models do not rely on maliciousness towards certain groups or informational asymmetries to generate disparities between groups. ${ }^{3}$ In these survey-based studies, individuals are asked directly about their discrimination and harassment experiences. Alternatively, experimental methods (including audit studies and correspondence testing) involving random assignment have been used to measure discrimination based on race, sex, or sexual orientation (e.g., Frith, 1981; Cross, et al, 1990; Turner, et al., 1991; Kenney and Wissoker, 1994; Riach and Rich, 1991, 1995, 2002; Neumark, et al., 1996; Weichselbaumer, 2001; Bertrand and Mullainathan, 2003). Finally, selection processes that are blind with respect to sex have been used to assess sex bias in the hiring of musicians (Goldin and Rouse, 2000) and in the acceptance of academic papers for publication (Blank, 1991).
} 
In this paper, we explore the relationship between various measures of an individual's racial identity (defined below) and his or her experiences of racial harassment. ${ }^{4}$ Racial harassment is a particularly blatant form of racism that is discriminatory by its very nature (see Shields and Wheatly Price, 2002a on this point). Moreover, little research effort has been devoted to the issue of racial harassment despite its significant social consequences (McClelland and Hunter, 1992). Unlike the residualbased discrimination literature, we will rely on direct information about the nature and extent of harassment individuals have faced. We are especially interested in assessing the extent to which harassment is related to a multifaceted concept of identity that is broader than simple racial group membership. Because the social context is relevant for the identities that individuals adopt (Akerlof and Kranton, 2000; Nkomo and Cox, 1996; Darity, et al., 2002; Fryer and Jackson, 2003), we are also interested in understanding how social prescriptions about the nature of inter-racial group interactions. Finally, we consider how institutional factors (such as, equal opportunity procedures and overall race relations) affect harassment levels.

In contrast to the previous identity literature, our contribution is mainly empirical. ${ }^{5}$ The issue of racial harassment seems to us to be a natural place to study the effects of identity groups. To the extent that racial identity matters at all, it seems quite sensible to expect it to factor into individuals' perceptions of inter-group relations. We

\footnotetext{
${ }^{4}$ In the analysis we will also consider harassment of Asians and Hispanics. Although harassment of these groups is more likely based on ethnicity rather than race, we will continue to refer to this as "racial" harassment for simplicity.

${ }^{5}$ The empirical identity literature is less well developed. Some researchers have estimated the extent to which adoption of "oppositional" identities may affect the labor market opportunities of ethnic groups (Battu, et al., 2003) and women (O'Reilly and O'Neill, 2003), while Bodenhorn and Ruebeck (2003) assess the factors driving the assignment of a mulatto identity in the 1860s. Other empirical evidence is more inferential. Fryer and Levitt (2003) argue, for example, that the growth in distinctly Black names is
} 
utilize data on a sample of active-duty personnel in the U.S. military captured in the 1996 Armed Forces Equal Opportunity Survey (AF-EOS). The U.S. military makes a particularly interesting case for studying issues related to racial harassment (see Section 4). Furthermore, large samples (even for minority group members), detailed information (including direct evidence on the social context and prescriptions about behavior) and the ability to identify military installations (workplaces) make the data particularly well suited to the task at hand.

Our results indicate that more than 65 percent of active-duty personnel experienced racially offensive behavior, and approximately one-in-ten reported threatening incidents or career-related racial discrimination. Interestingly, perceptions of harassment are driven by social classifications that extend beyond racial group membership. While race clearly matters, there is also significant diversity in the harassment experiences of individuals of the same race with diverging organizational, cultural or social experiences. Social prescriptions constraining inter-racial interactions are associated with higher rates of offensive racial encounters and more career-related discrimination, while aspects of an installation's institutional culture also directly affect racial harassment. Together, these results lend support for a model of racial harassment that encompasses both institutional factors and a multifaceted notion of racial identity.

In the next section of the paper, we describe the manner in which we model identity and racial harassment. The Armed Forces Equal Opportunity Survey and our strategy for measuring both identity and racial harassment are discussed in detail in Section 3, while our results are presented in Section 4. In Section 5, we cast our results 
in the light of the larger literature surrounding social identity. Brief conclusions follow in Section 6.

\section{Identity and Racial Harassment: The Issues and Estimation Model}

\subsection{Modeling Identity}

Historically, economists have implicitly modeled a simple one-to-one relationship between an individual's identity and his or her (usually exogenous) characteristics. In the case of race, for example, racial identity is usually given by:

$$
I_{i}=R_{i}
$$

where $I_{i}$ is the racial identity of individual $i$ and $R_{i}$ is his or her reported race. Racial groups are then formed through a simple aggregation of individuals. From this perspective, racial identity does not depend on the social context nor is there room for the nature or intensity of racial group identification to differ between individuals. This conceptualization of identity is somewhat incongruous with the fact that the vast majority of empirical research relies upon survey data in which individuals self-report their own race and ethnicity. ${ }^{6}$

It is also at odds with biological evidence rejecting race as a meaningful biological concept (see the discussion in Darity, et al., 2002, Bodenhorn and Ruebeck, 2003, and Austen-Smith and Fryer, 2003). Although readily observable physical

\footnotetext{
${ }^{6}$ Since 1960, the U.S. Census Bureau has relied on self-identification to determine racial and ethnic categories in its data sources making the process whereby individuals identify themselves as members of one group or another important for inter-group comparisons, particularly over time. For example, between 1960 and 1970 approximately 25 percent of the population growth of Native Americans resulted from changes in the self-identification process. Changes in self-identification accounted for 60 percent of Native-American population growth between 1970 and 1980, and 35 percent of growth between 1980 and 1990 (see Thornton, 1997 and references therein). See Skerry (2000) for a review of U.S. Census Bureau policy regarding the classification of race and ethnicity.
} 
characteristics (e.g., phenotype or sex) provide individuals with a mechanism for categorizing oneself and others, social science disciplines other than economics see racial identity as a social concept that is inherently more complex. ${ }^{7}$ Individuals prefer interacting with individuals perceived as similar to themselves, and the process of group identification is both fluid and context-dependent. Specifically, individuals are seen as altering the intensity of their identification with a racial reference group in response to changes in external factors (see Darity, et al. 2002; Austen-Smith and Fryer, 2003; Bodenhorn and Ruebeck, 2003; and the references therein). ${ }^{8}$

Here we abstract from the interesting issue of identity group formation. Dynamic, empirical models of identity group formation have not yet been developed, but would almost certainly require panel data on identity over time that we unfortunately do not have. Rather our interest in this paper is in assessing whether in the context of perceived racial harassment there is a case to be made for a notion of identity that: 1) extends beyond simple measures of race; 2) depends on social prescriptions about inter-racial relations; and 3) is context-dependent. Consequently, drawing on Akerlof and Kranton (2000) we model racial identity as:

$$
I_{i j}^{*}=\varphi_{i j}\left(X_{i j}^{\prime}, P_{j}, G_{i j}\right)
$$

where $j$ indexes location, $X_{i j}^{\prime}$ is a set of individual characteristics influencing an individual's identity, $P_{j}$ captures social prescriptions about how different racial groups

\footnotetext{
${ }^{7}$ Darity, et al. (2002) and Austen-Smith and Fryer (2003) summarize the way in which other social and behavioral sciences conceive of racial identity, while Akerlof and Kranton (2000) discuss some of the psychological evidence on group formation. Fryer and Jackson (2003) review the social psychology literature on the importance of categorization, particularly on race. Finally, Bodenhorn and Ruebeck (2003) discuss the empirical literature on the economic and social consequences of complexion.
} 
should interact with one another, while $G_{i j}$ is the set of different social categories (discussed below) to which individuals assign themselves and others.

One of the key insights from the social conformism and cultural identity literatures is that social groups may have incentives to punish individuals choosing to deviate from group norms. Individuals deviating from the relevant social customs face diminished status, a loss of social reputation, and reduced utility (Akerlof, 1980, 1987; Bernheim, 1994; Jones, 1984). For minority group members, pressure to conform may create a tension between what is necessary to be accepted by one's peers or social group and what is necessary to be successful in the majority culture (Austen-Smith and Fryer, 2003; Bodenhorn and Ruebeck, 2003). Consequently, social prescriptions regarding inter-group behavior $\left(P_{j}\right)$ act as a constraint on the formation of an individual's identity (Akerlof and Kranton, 2000).

In order to incorporate the notion of identity embodied in equation (2) into our analysis, it is also necessary to be more specific about the social categories $\left(G_{i j}\right)$ that we consider. Ideally, we would like to conceptualize these groups in a way that is relevant for perceptions of racial harassment in military employment. Social identity theory suggests that individuals tend to classify themselves (and others) into categories and further, that these classifications have important effects on human interactions (Nkomo and Cox, 1996). Race is frequently used as a means of classification (see Fryer and Jackson, 2003 and the references therein), though positive social interactions are expected to reduce prejudice and stereotyping leading the frequency of interactions

\footnotetext{
${ }^{8}$ This is not to suggest that individual's choices are unconstrained. In fact, Akerlof and Kranton (2000) argue that limits on this choice may be the most important determinant of individual well-being.
} 
between groups to be quite important (Nkomo, 1992). ${ }^{9}$ Finally, contextual forces, in particular, position within the wider organizational structure also act to shape inter-group relations. Alderfer and Smith (1982), for example, postulate that two distinct types of social groups exist within organizations: groups based on similar individual backgrounds (i.e., individuals who share common biological traits, histories, or social constraints) and groups based on similar organizational backgrounds (i.e., individuals who share a common organizational position or work experiences). Taking the latter into account is likely to be quite important given the hierarchical nature of military employment.

Drawing on these ideas, we define two separate organizational groups: the first based on military rank and the second based on work group characteristics. In addition, we define three alternative individual groups: one based on a shared cultural background and two based on shared social experiences (see Section 3.2 for details).

\subsection{Modeling Harassment}

Unlike the identity literature, the economics literature focusing on work-related harassment (as distinct from labor-market discrimination) is rather small and mainly empirical. ${ }^{10}$ Harassment is measured by asking individuals directly about events or situations that they have encountered and is perhaps better thought of as "perceived" rather than "actual" harassment. Given our interests, the ability to directly measure individuals' perceptions of racial harassment is preferable for several reasons. First, systematic differences in reported experiences among different groups of workers suggest

\footnotetext{
${ }^{9}$ Fryer and Jackson (2003) relate the frequency of social interactions to the precision with which individuals are able to categorize their experiences with others.
} 
that individuals' perceptions are not completely idiosyncratic. ${ }^{11}$ Consequently, even if harassment could be objectively measured, it may be perceptions of harassment that are important in understanding individual behavior. ${ }^{12}$ Furthermore, perceived harassment has negative consequences for workers in terms of lower job satisfaction and heightened intentions to leave ones job (Laband and Lentz, 1998; Shields and Wheatly Price, 2002b; Antecol and Cobb-Clark, 2001; 2004b). ${ }^{13}$ Most importantly, perceptions of inter-group relations are likely to provide a more direct test of the propositions of the identity model.

The research most directly related to ours is that of Shields and Wheatly Price (2002a; 2002b) who estimate a model of racial harassment using survey data for a sample of British nurses. They separately examine harassment initiated by work colleagues on the one hand and harassment initiated by patients and their families on the other. They conclude that individual, job, and workplace characteristics are all important for predicting harassment. ${ }^{14}$ Our interest in the usefulness of identity theory in understanding discrimination leads us to consider a more elaborate model of racial harassment. Specifically, we model the propensity to perceive racial harassment $\left(H_{i j}^{*}\right)$ as:

$$
H_{i j}^{*}=h_{i j}\left(\tilde{X}_{i j}, S_{j}, I_{i j}^{*}\right)
$$

\footnotetext{
${ }^{10}$ Although several theoretical models of labor market discrimination exist in the economics literature, corresponding models of harassment are notoriously absent. The exception is Basu $(2002 ; 2003)$ who models the circumstances under which it is sensible to ban sexual harassment.

${ }^{11}$ For example, Laband and Lentz (1998) note male lawyers' reports of having observed sexual harassment of female lawyers generally confirm the reports of their female colleagues.

${ }^{12}$ In particular, note that the legal system is "complaint-driven" relying on reports from individual workers to identify harassment and discrimination cases.

${ }^{13}$ This remains true even after the potential endogeneity of individuals' perceptions is taken into account (Shields and Wheatly Price, 2002b; Antecol and Cobb-Clark, 2001; 2004b).

${ }^{14}$ See Laband and Lentz (1998) and Antecol and Cobb-Clark (2001) for a similar assessment of sexual harassment.
} 
where $\tilde{X}_{i j}$ is a vector of demographic and human capital characteristics that are expected to have a direct impact on perceptions of racial harassment. Furthermore, drawing on research showing that training can heighten awareness of sexual harassment issues (Antecol and Cobb-Clark, 2003), we include in $\widetilde{X}_{i j}$ measures of respondents' awareness of racial harassment procedures and training experiences. Note that some elements of $\tilde{X}_{i j}$ may overlap with those characteristics influencing identity $\left(X_{i j}^{\prime}\right)$ in equation (2) (see the discussion below). There is also evidence that the incidence of harassment is related to the extent to which the organization is successful in creating a climate in which harassment is not tolerated (Williams, et al. 1997; Shields and Wheatly Price, 2002a; Antecol and Cobb-Clark, 2001). Consequently, $S_{j}$ characterizes the military installation itself (for example, the demographic composition of the installation and its "equal opportunity climate"). Finally, perceived harassment is also assumed to depend on identity $\left(I_{i j}^{*}\right)$.

\subsection{Reduced-Form Estimation Model}

While the above discussion outlines a theoretical framework for thinking about the effects of individual identity on perceptions of racial harassment, as an empirical framework it is somewhat limited because we do not have an obvious way of measuring "identity" in our data. ${ }^{15}$ This framework can be used, however, to generate a reducedform model that we can estimate. Furthermore, this theoretical framework is useful in

\footnotetext{
${ }^{15}$ In the empirical literature, "identity" is generally measured in diverse ways that are both ad hoc and data driven. Identity has, for example, been proxied by the assignment of racially-specific names (Fryer and Levitt, 2003; Aura and Hess, 2003) or mulatto classifications (Bodenhorn and Ruebeck, 2003) as well as by stated preferences for ethnic-based schools and within group marriage (Battu, et. al., 2003) or aggressiveness and supportiveness (O'Reilly and O’Neill, 2003).
} 
highlighting the interpretation issues that arise once we begin to allow for the possibility that individuals' perceptions of harassment depend on dimensions of their identity.

Equations (2) and (3) form the basis of our estimation model. Assuming linearity these equations can be rewritten as:

$$
\begin{gathered}
I_{i j}^{*}=X_{i j}^{\prime} b_{1}^{I}+P_{j} b_{2}^{I}+G_{i j} b_{3}^{I}+\varepsilon_{i j}^{I} \\
H_{i j}^{*}=\tilde{X}_{i j} b_{1}^{H}+S_{j} b_{2}^{H}+\lambda I_{i j}^{*}+\varepsilon_{i j}^{H}
\end{gathered}
$$

Substituting (2') into (3') and letting $X=\left(x_{1}, x_{2}, \ldots x_{k}\right)$ such that $X=X^{\prime} \cup \tilde{X}$, our reduced-form model of the propensity to experience racial harassment is given by:

$$
H_{i j}^{*}=X_{i j} \beta_{1}+S_{j} \beta_{2}+P_{j} \beta_{3}+G_{i j} \beta_{4}+\eta_{i j}
$$

where

$$
\begin{aligned}
& \beta_{1}=\left(\begin{array}{rl}
b_{1 k}^{H} & \text { if } x_{k} \in \tilde{X} \text { and } x_{k} \notin X^{\prime} \\
\lambda b_{1 k}^{I} & \text { if } x_{k} \notin \tilde{X} \text { and } x_{k} \in X^{\prime} \\
\left(b_{1 k}^{H}+\lambda b_{1 k}^{I}\right) & \text { if } x_{k} \in \tilde{X} \text { and } x_{k} \in X^{\prime}
\end{array}\right) \\
& \beta_{2}=b_{2}^{H} \\
& \beta_{3}=\lambda b_{2}^{I} \\
& \beta_{4}=\lambda b_{3}^{I} \\
& \eta_{i j}=\left(\varepsilon_{i j}^{H}+\lambda \varepsilon_{i j}^{I}\right)
\end{aligned}
$$

Inspection of equation (4) highlights that in fact there are three types of individual characteristics in the model: those that have only a direct effect on harassment, those that affect harassment only indirectly through their effect on identity, and those that have both direct and indirect effects. Although without more structure, it is not possible to separately identify the direct and indirect effects, this framework is useful in reminding us that reduced-form estimates will contain elements of both and are likely to be subject 
to multiple interpretations. At the same time, $\beta_{3}$ and $\beta_{4}$ identify the effects of social prescriptions and social categories on perceptions of harassment. These factors are assumed to affect racial harassment by influencing individuals' racial identity. The propensity to experience racial harassment is unobserved, so we create an indicator variable reflecting the presence or absence of reported harassment. Specifically,

$$
H_{i j}=1\left(H_{i j}^{*}>0\right)=Z_{i j} \beta+\eta_{i j}
$$

where $Z=\left(X_{i j}, S_{j}, P_{j}, G_{i j}\right)$ and we assume that $\eta_{i j} \sim N(0,1)$ and that $\eta_{i j}$ is independent of the explanatory variables in equation (5).

\section{The Armed Forces Equal Opportunity Survey}

We use data drawn from the public-use 1996 U.S. Armed Forces Equal Opportunity Survey (AF-EOS) combined with a randomized variable extracted from the confidential file that allows us to identify unique military installations. These data are uniquely suited to the analysis at hand. The public-use file provides us with detailed information on perceived racial harassment, $\left(H_{i j}\right)$ as well as demographic and human capital characteristics, $\left(X_{i j}\right)$. Additionally, the public-use AF-EOS contains information that allows us to construct social categories $\left(G_{i j}\right)$, while also providing information about institutional factors as well as social prescriptions regarding inter-racial interactions. Furthermore, the ability to identify unique military installations is extremely important 
for our purposes as it allows us to construct installation-level measures of the institutional factors $\left(S_{j}\right)$ and social prescriptions $\left(P_{j}\right)$ affecting harassment levels. ${ }^{16}$

Moreover, the U.S. military makes an interesting case for studying racial issues because it has historically been relatively integrated when compared to other social institutions and has consequently provided a key source of socioeconomic mobility for black Americans (Ellison, 1992). Furthermore, the nature of military employment makes managing group diversity especially challenging. Military personnel—particularly young enlisted men and women — live on military bases and are on duty 24 hours a day. This degree of proximity and the blurring of professional and personal relationships may increase both the incidence and subsequent psychological costs of harassment. In light of the need to recruit and retain high-quality personnel, some have suggested that in the future the U.S. military may find that "the equal opportunity climate of its units is one of its primary criteria of mission effectiveness" (Knouse, 1991, pg. 386).

The data generalize to personnel in the Army, Navy, Marine Corps, Air Force, and Coast Guard with at least six months of active-duty service who are below the rank of admiral or general. A non-proportional stratified random sample of active-duty personnel was drawn from the Defense Manpower Data Center's (DMDC's) April 1996 Active-duty Master File (ADMF). Data were stratified on the basis of service, location, pay level, and race/ethnicity. Minority groups were oversampled to ensure adequate numbers of minorities were available for analysis. Questionnaires were mailed to sample members between September of 1996 and January of 1997. From an initial eligible

\footnotetext{
${ }^{16}$ As Manski (1993) notes, specifying the reference group is a necessary first step in studying the effects of social groups. Military installations are a particularly useful measure of reference groups in our case because installations reflect geographically separate groups of individuals who live and work together and whose day to day experiences are ultimately under the command of a single individual.
} 
sample of 73,496 individuals $^{17}$, usable questionnaires were returned from 39,855 individuals for an overall response rate of 52.7 percent (Elig et. al. 1997 and Wheeless et. al. 1997).

We restrict our analysis to active-duty members with non-missing military installation codes because these codes are needed to construct our measures of institutional factors $\left(S_{j}\right)$ and social prescriptions $\left(P_{j}\right)$, (see Section 3.2 below). Unfortunately, installation codes are not generally available for overseas personnel and members of the Coast Guard and so these individuals have also been excluded from the sample. ${ }^{18}$ Moreover, we only consider installations for which we have a sample of at least 10 active-duty members in order to have sufficient precision for our installationlevel measures $\left(S_{j}\right)$ and $\left(P_{j}\right) .{ }^{19}$ Finally, we exclude Native Americans because we are unable to construct a number of social categories $\left(G_{i j}\right)$, for this group due to small cell sizes. These restrictions produce a final sample of 18,035 active-duty personnel with non-missing values for the key variables of interest. ${ }^{20}$

\subsection{Parameterizing Perceived Racial Harassment}

Personnel in the sample were asked which of 31 separate racial harassing incidents - initiated by another military member or a Department of Defense civilian-

\footnotetext{
${ }^{17}$ Although the initial non-proportional stratified random sample consisted of 76,754 active-duty personnel, 3,258 of them were found to be ineligible for the target population because they had left the military service (Elig et. al. 1997; Wheeless et. al. 1997).

${ }^{18}$ Approximately 40 (70) percent of overseas personnel (members of the Coast Guard serving in the United States) have missing installation codes, while roughly 13, 6, 4, and 4 percent of members of the Army, Navy, Marine Corps, and Air Force serving in the United States, respectively, have missing installation codes. Estimation results are similar if overseas active-duty personnel and members of the Coast Guard serving in the United States are included in the base model (see Section 4.1) and are available upon request. ${ }^{19}$ Similar results are found if we consider only those installations with at least 50 active-duty members and are available upon request.
} 
they had experienced in the previous 12 months. ${ }^{21}$ These incidents range from being subjected to offensive racist remarks and being told racist jokes, to being evaluated unfairly based on race and being assaulted physically because of race. Following Scarville et. al. (1997), we combine the responses to the 31 separate items in the 1996 AF-EOS into three broad categories: 1) offensive encounters, 2) threatening encounters, and 3) career-related incidents. While the latter essentially measures racial discrimination, the former two are more sensibly thought of as racial harassment per se. ${ }^{22}$ Psychologists studying prejudice argue that discrimination is often motivated by preferential treatment of in-group members rather than direct hostility towards out-group members (Brewer, 1999), suggesting that the determinants of discrimination and harassment are likely to differ. However, for ease of exposition we shall refer to all three measures as "harassment".

Table 1 presents the mean incidence (and standard deviation) of each type of racial harassment reported by racial group. Overall, offensive encounters are the most frequently reported form of racially harassing behavior (65.2 percent), with career-related (13.0 percent) and threatening incidents (9.5 percent) occurring less frequently. This general pattern holds within racial groups, although there exists substantial diversity in perceived harassment across groups. No racial group is uniformly more likely to report every type of harassing behavior. In particular, reports of offensive encounters are

\footnotetext{
${ }^{20}$ Due to item non-response, estimation samples range between 17,297 and 18,035 .

${ }^{21}$ Personnel in the sample were also asked about a range of incidents of racial harassment initiated by civilians in the local community surrounding the military base. Community-based harassment is beyond the scope of this paper and is a topic of current research.

${ }^{22}$ Scarville et. al. (1997) used a principal component analysis with orthogonal rotation to assign each of the 31 types of encounters into six broad categories. As four of their categories (assignment/career, evaluation, punishment, and training/test scores) all pertain to racial discrimination with respect to aspects of ones military career, we have combined these four categories into one broad category which we label "career-
} 
highest among Hispanics (78.1 percent), while reports of threatening encounters and career-related incidents are highest among Asians (15.1 percent) and among blacks (29.1 percent), respectively. White active-duty personnel are less likely to report all types of harassing behavior than are their non-white counterparts, though the majority (60.9 percent) of white personnel also report being subjected to racially offensive encounters. This rate is considerably higher than the incidence of racial harassment reported by white British nurses, even though harassment levels among non-white military personnel and British nurses are often quite similar (see Shields and Wheatly Price, 2002a). Approximately three in four individuals reported experiencing at least one adverse outcome resulting from their racial harassment experience (see Appendix Table 3) suggesting that these experiences are not trivial.

\section{Table 1 Here}

\subsection{Parameterizing Social Categories, Social Prescriptions, and Institutional Factors}

As discussed in Section 2, social identity theory suggests that social categories within organizations $\left(G_{i j}\right)$ stem from both individual and organizational groupings. While individual groups form on the basis of shared biological traits, histories, or social constraints, organizational groups form on the basis of similar organizational position or work experiences. We operationalize this idea by defining two organizational groups: one based on rank and the second based on work group characteristics (including whether the respondent is in a work environment where members of their race are uncommon combined with whether the race of their supervisor is different from their own). We also

related". The remaining categories are identical to those considered by Scarville et. al. (1997). See Appendix Table 1 for a detailed list of the specific behaviors that make up each type of racial harassment. 
define three individual groups. The first focuses on cultural background (i.e., nativity status and whether English is the respondent's first language). The second two are based on uncomfortable social experiences including a decline in inter-racial friendships since joining the military ${ }^{23}$ and the frequency (and unease) with which the individual socializes with friends of a different race. ${ }^{24}$ In all cases, our social categories are fully interacted with respondents' race.

Social prescriptions about individual behavior are also central to an individual's identity. In particular, both the social conformism and the cultural identity literatures share the view that individuals' desire to be accepted by their peers or social group may lead them to conform to group norms of behavior even when those norms are in conflict with those of wider society. Consequently, social prescriptions act as a constraint on an individual's identity. One of the strengths of the AF-EOS data is that they provide direct measures - at an installation level—of the social prescriptions $\left(P_{j}\right)$ governing how different racial groups should interact with each other. In particular, respondents reported the extent to which: 1) they felt pressure from service members belonging to their own racial group not to socialize with members of other racial groups; (2) people feel free to sit wherever they choose in the dining halls regardless of race; (3) people feel free to use any recreation facilities regardless of race; (4) members of a racial group are treated as if they are "trouble" when they get together; and (5) personnel prefer to socialize with members of their own racial group when they are off duty. Each question was answered

\footnotetext{
${ }^{23}$ Respondents were asked the following question: "Compared to right before you entered the military, do you have more or fewer close personal friends who are of a race/ethnicity different than yours?" Individuals are coded as one if they report fewer friends now, and zero otherwise.

${ }^{24}$ Frequency of inter-racial interaction is based on the following question: "Do you have friends of a different race/ethnicity with whom you socialize in your home/quarters?" A respondent is coded as one if they responded yes, and zero otherwise. While ease of inter-racial interaction is based on the following
} 
on a 1 (not at all) to 5 (to a very large extent) scale. ${ }^{25}$ We first create an aggregate index ranging from 5 to 25 for each respondent by adding up the individual's responses to each of the five questions. ${ }^{26}$ Higher values of the index indicate fewer constraints on interracial interactions. $P_{j}$ is then calculated by assigning to each individual the weighted average of the aggregate social prescriptions index of his or her installation.

Finally, we are interested in the ways that institutional factors affect the incidence of harassment. Our strategy is to directly control for those factors affecting an installation's demographic composition and equal opportunity (EO) climate $\left(S_{j}\right)$. Because EO climate may be determined in part by institutional factors relating to personnel policies, training opportunities, etc. that may differ across branches of the military $S_{j}$ includes dummy variables for service. In addition, $S_{j}$ incorporates aggregate measures of 1) the rate of racial confrontation; 2) the perceived probability of repercussions for reporting harassment; 3) the overall quality of race relations; 4) the availability of harassment hotlines; 5) the availability of formal complaint channels; along with 6) the proportion of installation personnel who are white. ${ }^{27}$ These aggregate

question: "To what extent do you feel competent interacting with people from different racial/ethnic groups?" A respondent is coded as one if they responded not at all or small extent, and zero otherwise.

${ }^{25} \mathrm{We}$ rescaled (1), (4) and (5) in the opposite direction in order for the higher values to reflect fewer constraints on inter-racial interactions.

${ }^{26}$ If the respondent did not answer all 5 questions, then for the question(s) they missed they were given their mean response from the question(s) they did answer.

${ }^{27}$ In calculating these measures we first created six indicator variables as follows: 1) racial confrontationequaling one if the respondent either saw (or experienced) racial confrontation in the past 12 months on their installation/ship; 2) repercussions - equaling one if the respondent to a (very) large extent feels free to report racial harassment on their installation/ship without the fear of repercussions; 3) positive race relations - equaling one if the respondent to a (very) large extent believes race relations are good on their installation/ship; 4) hotlines - equaling one if the respondent indicates the existence of a hotline for racial harassment on their installation/ship; 5) formal complaint channels-equaling one if the respondent indicates the existence of a formal racial harassment complaint channel on their installation/ship; and 6) white - equaling one if the respondent is white. In all other cases - including item non-response - these six indicator variables are coded as zero. Weighted, installation-specific averages are then calculated and assigned to each individual. In preliminary estimation we also considered other measures including the 
variables are calculated by assigning each individual the weighted average rate of the variable of interest of his or her installation.

\section{Identity and Perceived Racial Harassment: Empirical Results}

We begin by estimating a baseline model of harassment that provides us with a point of reference from which to make comparisons to the existing literature. We then turn to estimation of our reduced-form harassment model set out in equation (5) in order to assess the extent to which multi-faceted identity and the social context affect the incidence of perceived racial harassment.

\subsection{Results from the Baseline Harassment Model}

In model 1, racial harassment is a function of an individual's race, awareness of racial harassment programs, demographic characteristics (gender and marital status) and human capital (education and years of active-duty service) ${ }^{28}$ Results (probit marginal effects and robust standard errors) are reported in Table $2 .^{29}$

\section{Table 2 Here}

Consistent with previous evidence for British nurses (see Shields and Wheatly Price, 2002a; 2002b), military personnel perceive more racial harassment if they are members of a minority group. For example, relative to their white, non-Hispanic

percent of personnel who are female or in specific racial categories. These measures were not significant and were subsequently dropped from the analysis.

${ }^{28}$ Awareness of racial harassment programs is captured through three dummy variables indicating whether the respondent 1) had participated in a racial harassment awareness training program; 2) believed the installation had a racial harassment hotline; and 3) believed that the installation had a formal racial harassment complaint channel. Summary statistics are reported for all our explanatory variables in Appendix Table 2.

${ }^{29}$ In all models, we have accounted for clustering on installations when calculating standard errors. 
colleagues, black personnel are 12.6 percentage points more likely to report offensive racial encounters, 4.1 percentage points more likely to report racially threatening encounters, and 20.9 percentage points more likely to report career-related racial discrimination. Although direct comparisons are difficult, it is interesting that the magnitude of these racial group differences are much smaller than those reported by Shields and Wheatly Price (2002a). However, like these authors, we also generally find that men report more racial harassment than women, while the decline in perceived harassment with years of active-duty service parallels their finding that harassment is experienced more often by younger nurses.

\subsection{The Effects of Identity on Perceived Racial Harassment}

We turn now to consider a more intricate notion of identity. In model 2, identity continues to be proxied by race, while model 3 is based on equation (5) in which both social prescriptions $\left(P_{j}\right)$ and social categories $\left(G_{i j}\right)$ are allowed to affect perceived racial harassment through their effect on racial identity. Both models control for institutional factors $\left(S_{j}\right){ }^{30}$ Models $3 \mathrm{a}$ and $3 \mathrm{~b}$ include our two measures of organizational groups, while models 3c-3e include our three measures of individual groups (see Section 3.2 for details). ${ }^{31}$

Tables 3 - 4 Here

\footnotetext{
${ }^{30}$ Results for $S_{j}$ will be discussed in detail in Section 4.3 below.

${ }^{31}$ Specifically, we report selected probit marginal effects and robust standard errors. See Tables 3 and 4 for complete list of the control variables included each in model.
} 
Social prescriptions constraining individuals' choice of racial identity lead to consistently higher rates of perceived harassment. Specifically, those military installations with a $P_{j}$ index two points higher (i.e, twice the standard deviation) indicating fewer constraints on inter-group interactions have approximately 7.4 percent fewer offensive encounters, and 24.6 percent fewer reports of career-related discrimination. ${ }^{32}$ At the same time, our measures of social prescriptions are unrelated to reports of threatening racial incidents. Brewer (1999) argues that many forms of hostility and antagonism towards out-group members do not stem from identification with a particular social group, but may reflect individual attitudes similar to phobias. If this is true with respect to racial threats and violence, it is perhaps not surprising that this form of harassment is not affected by social prescriptions. Further, these differences lend support to those who argue that racial harassment should be distinguished from racial violence or racial prejudice (see McClelland and Hunter, 1992).

Given the importance of reported race as a mechanism for classifying oneself and others (Fryer and Jackson, 2003), it seems sensible that race should play a central role in our conceptualization of social categories $\left(G_{i j}\right)$. Indeed comparison of models 1 and 2 suggests that although the effect of racial group membership on perceived harassment is somewhat mitigated once we control directly for institutional factors, racial differences in perceived harassment continue to be quite important. At the same time, results from models $3 a-3 e$ indicate that there is significant disparity in the experiences of individuals within the same racial group. For example, white personnel whose co-workers are predominately of a different race report significantly higher rates of offensive encounters

\footnotetext{
${ }^{32}$ This is calculated by doubling the estimated coefficient on the social prescription index, dividing by the
} 
(15.5 percentage points), racial threats ( 7.8 percentage points), and career-related discrimination (19.7 percentage points) than their white colleagues who predominately work with other whites (see model 3b). Similarly, military personnel with fewer interracial friendships since joining the military report significantly more harassment than others of the same race whose inter-racial friendships have not declined (see model 3d).

These patterns raise the question: Is social categorization about more than race? In order to get insight into this question, define $\hat{\gamma}_{g r}$ to be the estimated effect of groupi.e., rank, work group, cultural group, etc.—membership (indexed by g) and respondent race (indexed by $r$ ). ${ }^{33}$ We can then test the following two propositions:

$$
\begin{array}{ll}
H 1: & \hat{\gamma}_{1 r}=\hat{\gamma}_{2 r}=\ldots=\hat{\gamma}_{n r} \forall r \\
H 2: & \hat{\gamma}_{g 1}=\hat{\gamma}_{g 2}=\ldots=\hat{\gamma}_{g m} \forall \mathrm{g}
\end{array}
$$

where $g=(1,2, \ldots n)$ and $r=(1,2, \ldots m)$. The first proposition (H1) implies that within race, perceptions of racial harassment do not differ between members of different groups. Alternatively, the second proposition (H2) implies that within groups, perceptions of racial harassment do not differ between members of different races. If racial group membership completely captured social categories we would expect that we could not reject $\mathrm{H} 1$. On the other hand, $\mathrm{H} 2$ provides a test of whether group membership in the absence of race is an adequate measure of social categorization. These two propositions are tested using standard joint hypothesis tests and the p-values are reported in Table 5.

\section{Table 5 Here}

overall mean of the respective harassment measure, and then multiplying by 100 .

${ }^{33}$ Given our model $\hat{\beta}_{4}=\hat{\gamma}_{g r}$. These are the results reported in Tables 3 and 4. 
The overarching conclusion to be drawn from the results in Table 5 is that neither race nor group membership is, on its own, completely sufficient to capture the relationship between social classification — and consequently racial identity—and perceived harassment. In general, there are significant racial differences in perceived harassment among individuals sharing the same social or cultural background or organizational position, but there are also significant differences in the harassment rates of individuals of the same race belonging to different organizational or individual social groups. In this context, racial identity would seem to stem from the complex interaction of racial, organizational, and individual group membership. ${ }^{34}$

What is perhaps most interesting are the exceptions to this general result. In particular, group membership occasionally seems to be less important than race in explaining perceived harassment. For example, black and Asian officers report offensive behavior at the same rate as their enlisted colleagues (see model 3a). Similarly, within racial groups, reports of harassment are generally the same irrespective of whether or not the individual socializes with others of a different race and if so the ease with which they do it (see model 3e). There are, however, several instances where race is less important then group membership. For example, foreign-born Asians and Hispanics who speak English as their first language are equally likely to report experiencing offensive racial harassment (see model 3c) and individuals in work groups where their race is uncommon report experiencing threatening racial harassment at the same rate regardless of whether they are white, black, Hispanic, or Asian (see model 3b).

\footnotetext{
${ }^{34}$ Alderfer and Smith (1982), in particular, noted the importance of these types of interactions in understanding the challenges of managing organizational diversity.
} 
On balance, the results in Tables $3-5$ suggest that the model of racial identity outlined in equation (2) is useful in enhancing our understanding of the factors underlying perceptions of racial harassment. In particular, in all cases standard likelihood ratio tests reject $(\mathrm{p}<0.01)$ the standard economic model of racial identity based solely on racial group membership (model 2) in favor of a model that incorporates both social categories and prescriptions regarding inter-racial relationships (model 3). ${ }^{35}$

\subsection{The Role of Institutional Factors}

The estimated effects of an installation's demographic composition and equal opportunity climate on harassment are reported in Table 6. Although these results come from the same regressions underlying Tables 3 and 4, for convenience we present them here separately.

\section{Table 6 Here}

Relative to their counterparts in the Army, active-duty personnel in the Air Force report significantly fewer incidents of all types of racial harassment, while personnel in the Marine Corp report fewer career-related incidents of discrimination. It is interesting that higher levels of racial confrontation are associated with increased probabilities of both offensive and threatening encounters (as might be expected), though improvements in the installation's overall race relations are associated with an increased probability that military personnel report experiencing career-related racial discrimination. This latter result is perhaps not surprising when we consider that the factors driving career-related

\footnotetext{
${ }^{35}$ The single exception is we reject model 2 in favor of model 3e only at the 10 percent significance level when considering threatening racial encounters.
} 
discrimination are likely to differ from those driving harassment per se. In particular, it is possible that better race relations may be associated with implicit expectations of more rapid career advancement which minority personnel have not realized. Consistent with Shields and Wheatly Price (2002a), the existence of formal EO policies (i.e., hotlines and channels) and the demographic composition of the workforce seem to bear little relationship to the incidence of racial harassment.

At the same time, controlling for racial identity, institutional factors are in general quite important in understanding harassment rates. In all cases, the elements of $S_{j}$ are jointly significant at the one percent level. These measures of the equal opportunity climate and demographic composition of a military installation - in conjunction with social prescriptions on inter-racial relations $\left(P_{j}\right)$-explain between 35 and 40 percent of the installation-specific variation in harassment levels. ${ }^{36}$ Furthermore, Breusch-Pagan (1980) tests indicate that any remaining (unobserved) effect of military installations themselves are unimportant in understanding harassment levels once $S_{j}$ and $P_{j}$ are controlled. ${ }^{37}$

\footnotetext{
${ }^{36}$ To gauge the predictive power of our installation-specific controls $P_{j}$ and $S_{j}$, we estimated a base model that included controls for social categories $\left(G_{i j}\right)$, but excluded both $P_{j}$ and $S_{j}$. We then estimated an unrestricted model in which a complete set of indicator variables for military installations were added to the base model to control for installation-specific fixed effects including institutional factors and social prescriptions. (This is equivalent to a fixed-effects specification of models $3 a-3 e$.) We compared the Rsquared from this unrestricted model to both the base and restricted models $3 a-3 e$ as follows:

$$
\% \text { Explained by EO Climate }=\frac{\left(R_{R}^{2}-R_{B}^{2}\right)}{\left(R_{U}^{2}-R_{B}^{2}\right)}
$$

This calculation indicates that while installation-specific effects increase the explanatory power of the model relative to the base model (the denominator in equation 5), our installation-specific controls capture a large fraction of this additional increase in explanatory power. The remainder can be attributed to heterogeneity in installations that is unobserved in our data.

${ }^{37} \mathrm{We}$ investigated this issue by using an unweighted, linear probability model including an unobserved, installation-specific effect in equation (5). We fail to reject the hypothesis that these installation-specific effects are equal to 0 .
} 


\section{Discussion:}

Though direct evidence is sparse, racial harassment would seem to be prevalent in many working environments. Approximately, two-thirds of active-duty personnel in the U.S. military report experiencing some form of offensive racial incident in the previous 12 months, while ethnic minority nurses working in the British National Health System (NHS) report remarkably similar rates of racial harassment from patients and their families (Shields and Wheatly Price, 2002a). Fully one in ten individuals in our military sample report having their property vandalized or being physically threatened as a result of their race. A similar proportion of active-duty personnel feel that racial discrimination has hampered their access to training or promotion opportunities.

Further, these forms of harassment have important consequences for victims (see Appendix Table 3). Harassment victims report feeling anger and rage (55.8 percent), sadness and depression (23.7 percent), a loss of trust in co-workers (36.8 percent) and supervisors (35.6 percent), stress, anxiety, and fear (32.7 percent), and low self-esteem (12.8 percent). Incidents of racial harassment and discrimination in promotion and training opportunities are the most important determinants of job satisfaction for British nurses (Shields and Wheatly Price, 2002b) and are indirectly linked to an increased probability of intending to leave the British NHS. Racial harassment also diminishes satisfaction with and heightens intentions to leave employment in the U.S. military (Antecol and Cobb-Clark, 2004b).

Allowing racial identity to extend beyond simple racial group membership adds depth to our understanding of the causes and consequences of racial harassment. In particular, racial identity based on a complex set of social categories and individual characteristics 
and constrained by social prescriptions about inter-racial behavior explains the variation in perceived harassment in a way that simple consideration of exogenous race does not. Racial group membership is not sufficient to capture the relationship between racial identity and perceived racial harassment. The reported incidence of racially threatening encounters, for example, is driven less by race than by whether one shares the same race with ones colleagues and supervisor (see Table 5), while those foreign-born personnel for whom English is not their native language often report much higher harassment levels than their foreign-born English-speaking counterparts (see Table 4). At the same time, race cannot be ignored. There are significant differences in perceptions of harassment among individuals of different races groups who share the same cultural or social backgrounds or organizational positions.

Importantly, we also find clear evidence that social prescriptions related to individuals' racial identities influence perceptions of racial harassment. Individuals based at military installations with fewer constraints on inter-racial interactions report significantly fewer offensive racial encounters, and significantly less career-related discrimination. Interestingly, this is consistent with other evidence that in the midnineteenth century those cities with fewer informal norms against social interactions also provided more economic opportunities for black and biracial individuals (Bodenhorn and Ruebeck, 2003).

The institutional context in which social interactions take place also clearly plays an important role in shaping the outcomes of those interactions (see for example, Akerlof and Kranton, 2000; Nkomo, 1992; Nkomo and Cox, 1996; Darity, et al., 2002; Fryer and Jackson, 2003; Milliken and Martins, 1996). Higher levels of racial confrontation, for 
example, are associated with increased probabilities of both offensive and threatening encounters, though improvements in an installation's overall race relations are associated with an increased probability that military personnel report experiencing career-related racial discrimination. These differentials point to a need for the development of theoretical frameworks that focus on racial harassment as distinct from racial discrimination.

Moreover, social contact theory predicts that frequent positive interactions decrease stereotyping and prejudice between social groups (Nkomo, 1992; Fryer and Jackson, 2003) and we find some indirect evidence in support of this proposition. Those individuals reporting that they have fewer friends outside their racial group since joining the military—which may indicate negative experiences—also report harassment rates that are often more than twice as high. At the same time, personnel who socialize with individuals of a different race-and are comfortable in inter-racial interactionsgenerally do not often seem to report lower harassment rates than their counterparts who do not socialize or if they do are uneasy about it.

Given that experiences of racial harassment are related to the institutional and social context in which military personnel live and work, policies targeted toward reducing racial confrontation and promoting inter-racial interactions are likely to be an obvious choice if the military's goal is to reduce the incidence of racial harassment. At the same time, such policies are not likely to be a panacea given evidence that improved racial relations increase reports of career-related racial discrimination and that, within racial groups, perceptions of harassment are not generally affected by how often (and easily) military personnel socialize with others of a different race. 
It is of course difficult to know to what extent these results for military personnel might be extended to other groups of workers. Historically, the U.S. military has been relatively integrated when compared to other social institutions, and the nature of military employment leads to a blurring of professional and personal relationships as military personnel-particularly young enlisted men and women-live and work in close proximity with others who may be outside their social group. There is also evidence that black veterans have less racial identification than non-veterans (Ellison, 1992), though whether this stems from the process whereby individuals self-select into the military or the military experience itself remains unclear. These aspects of military employment may serve to increase the frequency of inter-racial interactions and lead to a reduction in prejudice and stereotyping. At the same time, minority members of the military do not have the same protection from racial discrimination as the rest of the population due to a series of court decisions that have held that Title VII of the Civil Rights Act of 1964 pertains only to civilian employees of the armed forces (Smither and Houston, 1991). Complaints about discrimination are addressed through military rather than civilian courts and this difference in legal protection from racial discrimination may result in differential rates of racial harassment.

\section{Conclusions:}

Our results indicate that racial harassment is prevalent in the U.S. military with two in three military personnel experiencing some form of racially offensive encounter, and approximately one in ten reporting threatening incidents or career-related racial discrimination. Interestingly, perceptions of racial harassment are driven by multifaceted 
social classifications. While race clearly matters, there is also significant diversity in the harassment experiences of individuals of the same race with diverging organizational, cultural or social experiences. Social prescriptions constraining inter-racial interactions are associated with higher rates of offensive racial encounters and more career-related discrimination, while aspects of an installation's institutional culture also directly affect racial harassment. Together, these results suggest that a notion of racial identity that extends beyond simple racial group membership and is constrained by social norms - in conjunction with institutional factors - can be helpful in enhancing our understanding of the factors driving perceptions of racial harassment. 


\section{References:}

Akerlof, George A., 1980. "A Theory of Social Custom, of Which Unemployment May Be One Consequence", Quarterly Journal of Economics, 94(4), June, pp. 749775.

Akerlof, George A., 1997. "Social Distance and Social Decisions", Econometrica, 65(5), September, pp. 1005-1027.

Akerlof, George A. and Rachel E. Kranton, 2000. "Economics and Identity", The Quarterly Journal of Economics, 115(3), August, pp. 715-753.

Alderfer, Clayton P. and Ken K. Smith, 1982. "Studying Intergroup Relations Embedded in Organizations”, Administrative Science Quarterly, 27(1), March, pp. 35-65.

Antecol, Heather and Deborah A. Cobb-Clark, 2001. "The Sexual Harassment of Female Active-Duty Personnel: Effects on Job Satisfaction and Intentions to Remain in the Military", IZA Discussion Paper, no. 379, October.

Antecol, Heather and Deborah A. Cobb-Clark, 2003. "The Effect of Sexual Harassment Training on U.S. Federal Government Employee's Views of Unwanted Sexual Behavior at Work", Social Science Quarterly, 84(4), December, pp. 826-842.

Antecol, Heather and Deborah A. Cobb-Clark, 2004a. "The Changing Nature of Employment-Related Sexual Harassment: Evidence from the U.S. Federal Government (1978-1994)", Industrial and Labor Relations Review, forthcoming.

Antecol, Heather and Deborah A. Cobb-Clark, 2004b. "Racial Harassment, Job Satisfaction and Intentions to Remain in the Military", unpublished working paper.

Antecol, Heather and Peter Kuhn, 2000. "Gender as an Impediment to Labor Market Success: Why do Young Women Report Greater Harm?", Journal of Labor Economics, 18(4), October, pp. 702-728

Aura, Sakue and Gregory D. Hess, 2003. "What's in a Name?", unpublished working paper.

Austen-Smith, David and Roland, Fryer, Jr., 2003. "The Economics of 'Acting White'”, NBER Working Paper 9904, August.

Armed Forces Equal Opportunity Survey [CD-ROM]. (2000). Arlington, VA: DMDC [Producer and Distributor].

Baldwin, James 1985. "No Name in the Street" in The Price of the Ticket, New Your: St Martin's/Marek, pp. 449-552. 
Battu, Harminder, McDonald Mwale, and Yves Zenou, 2003. "Do Oppositional Identities Reduce Employment for Ethnic Minorities”, IZA Discussion Paper, 721, February.

Basu, Kaushik. 2002. "Sexual Harassment in the Workplace: An Economics Analysis with Implications for Worker Rights and Labor Standards Policy." unpublished paper, Massachusetts Institute of Technology.

Basu, Kaushik. 2003. "The Economics and Law of Sexual Harassment in the Workplace.” Journal of Economic Perspectives, 17(3), Summer, pp. 141-157.

Becker, Gary, 1971. The Economics of Discrimination, second edition. Chicago, IL: University of Chicago Press.

Bernheim, B. Douglas, 1994. “A Theory of Conformity”, Journal of Political Economy, 102(5), October, pp. 841-877.

Bertrand, Marianne and Sendhil Mullainathan, 2003. "Are Emily and Greg More Employable than Lakisha and Jamal? A Field Experiment on Labor Market Discrimination", NBER Working Paper 9873, July.

Blank, Rebecca. 1991. "The Effects of Double-Blind versus Single-Blind Refereeing: Experimental Evidence from the American Economic Review", American Economic Review, 81(5), December, pp. 1041-1067.

Bodenhorn, Howard and Christopher S. Ruebeck, 2003. "The Economics of Identity and the Endogeneity of Race", NBER Working Paper 9962, September.

Breusch, Trevor and Adrian Pagan, 1980. "The Lagrange Multiplier Test and its Application of Model Specification in Econometrics", Review of Economic Studies, 47(1), pp. 239-253.

Brewer, Marilynn B., 1999. "The Psychology of Prejudice: Ingroup Love or Outgroup Hate?", Journal of Social Issues, 55(3), pp. 429-444.

Cross, Harry with Genevieve Kenney, Jane Mell, and Wendy Zimmerman. 1990. Employer Hiring Practices: Differential Treatment of Hispanic and Anglo Job Seekers, Urban Institute Report 90-4. Washington, DC: The Urban Institute.

Darity, William A. Jr., Patrick L. Mason, and James B. Stewart, 2002. "The Economics of Identity: The Origin and Persistence of Racial Norms", unpublished working paper.

Elig, Timothy W., Jack E. Edwards, and Richard A. Riemer, 1997. Armed Forces 1996 Equal Opportunity Survey: Administration, Datasets, and Codebook (Report No. 97-026). Arlington, VA: Defense Manpower Data Center. 
Ellison, Christopher G., 1992. "Military Background, Racial Orientations, and Political Participation among Black Adult Males", Social Science Quarterly, 73(2), June, pp. 360-378.

Frijters, Paul, 1998. "Discrimination and Job-Uncertainty", Journal of Economic Behavior and Organization, 36(4), September, pp. 433-446.

Fryer, Roland Jr. and Matthew O. Jackson, 2003. "Categorical Cognition: A Psychological Model of Categories and Identification in Decision Making", unpublished working paper.

Fryer, Roland Jr. and Steven D. Levitt, 2003. "The Causes and Consequences of Distinctly Black Names", NBER Working Paper 9938, August.

Frith, Michael. 1981. "Racial Discrimination in the British Labor Market", Industrial and Labor Relations Review, 34 (2), January, pp. 265-272.

Goldin, Claudia and Cecilia Rouse, 2000. "Orchestrating Impartiality: The Impact of "Blind" Auditions on Female Musicians", American Economic Review, 90(4), September, pp. 715-741.

Hallock K.F., W. Hendricks, and E. Broadbent, 1998. "Discrimination by gender and disability status: Do worker perceptions match statistical measures?", Southern Economic Journal, 65 (2), October, pp. 245-263.

Hampton, Mary B. and John S. Heywood, 1993. "Do Workers Accurately Perceive Gender Wage Discrimination?" Industrial and Labor Relations Review, 47(1), October, pp. 36-49.

Johnson, Richard W. and David Neumark, 1997. "Age Discrimination, Job Separations, and Employment Status of Older Workers: Evidence from Self-Report." Journal of Human Resources, 32(4), Fall, pp. 779-811.

Jones, Stephen, 1984. The Economics of Conformism, Oxford: Blackwell, 1984.

Kenney, Genevieve M. and Douglas A. Wissoker, 1994. "An Analysis of the Correlates of Discrimination Facing Young Hispanic Job-Seekers" American Economic Review, 84(3), June, pp. 674-683.

Knouse, Stephen B., 1991. "Introduction to Racial, Ethnic and Gender Issues in the Military: The Decade of the 1900s and Beyond", International Journal of Intercultural Relations, 15(4), pp. 385 - 388.

Kuhn, Peter. 1987. "Sex Discrimination in Labor Markets: The Role of Statistical Evidence", American Economic Review, 77(4), September, pp. 567-583. 
Laband, David N., and Bernard F. Lentz. 1998. "The Effects of Sexual Harassment on Job Satisfaction, Earnings, and Turnover Among Female Lawyers." Industrial and Labor Relations Review, 51(4), July, pp. 594-607.

Manski, Charles F., 1993. "Identification of Endogenous Social Effects: The Reflection Problem", The Review of Economic Studies, 60(3), July, pp. 531-542.

McClelland, Kent and Christopher Hunter, 1992. "The Perceived Seriousness of Racial Harassment", Social Problems, Vol. 39(1), February, pp. 92 - 107.

Milliken, Frances J. and Luis L. Martins, 1996. "Searching for Common Threads: Understanding the Multiple Effects of Diversity in Organizational Groups", The Academy of Management Review, 21(2), April, pp. 402-433.

Neumark, David, Roy J. Bank, Kyle D. Van Nort, 1996. "Sex Discrimination in Restaurant Hiring: An Audit Study", The Quarterly Journal of Economics, 111(3), August, pp. 915-941.

Nkomo, Stella M., 1992. "The Emperor Has No Clothes: Rewiring "Race in Organizations", The Academy of Management Review, 17(3), July, pp. 487-513.

Nkomo, Stella M. and Taylor Cox, Jr., 1996. "Diverse Identities in Organizations", in Handbook of Organizational Studies (S.R. Clegg, C. Hardy, and W.R. Nord, editors), London: Sage.

O'Reilly, Charles A. III and Olivia A. O'Neill, 2003. "Women's Careers: The Impact of Sex and Gender Identity on Career Attainment", Research Paper No. 1775, Stanford Graduate School of Business, January.

Riach, Peter A. and Judith Rich, 1991. "Testing to Racial Discrimination in the Labor Market”, Cambridge Journal of Economics, 15(3), pp. 239-259.

Riach, Peter A. and Judith Rich, 1995. "An Investigation of Gender Discrimination in Labor Hiring", Eastern Economic Journal, 21(3), pp. 343-356.

Riach, Peter A. and Judith Rich, 2002. "Field Experiments of Discrimination in the Market Place", The Economic Journal, 112(483), November, pp. F480-F518.

Scarville, Jacquelyn, Scott B. Button, Jack E. Edwards, Anita R. Lancaster, and Timothy W. Elig, 1997. Armed Forces Equal Opportunity Survey (Report No. 97-027). Arlington, VA: Defense Manpower Data Center.

Shields, Michael A. and Stephen Wheatly Price, 2002a. "The Determinants of Racial Harassment at the Workplace: Evidence from the British Nursing Profession", British Journal of Industrial Relations, 40(1), March, pp. 1-21. 
Shields, Michael A. and Stephen Wheatly Price, 2002b. "Racial Harassment, Job Satisfaction and Intentions to Quit: Evidence from the British Nursing Profession", Economica, 69(274), May, pp. 295-326.

Skerry, Peter, 2000. Counting on the Census? Race, Group Identity, and the Evasion of Politics. Washington, DC: The Brookings Institute.

Smither, Robert D. and Mary Ruth Houston, 1991. "Racial Discrimination and Forms of Redress in the Military", International Journal of Intercultural Relations, 15(4), pp. 459-468.

Thornton, Russell, 1987. "Tribal Membership Requirements and the Demography of 'Old' and 'New' Native Americans", Population Research and Policy Review, 16(1/2), April, pp. 33-42.

Turner, Margery Austin, Michael Fix, and Raymond J. Struyk, 1991. Opportunities Denied, Opportunities Diminished: Racial Discrimination in Hiring, Urban Institute Report 91-9. Washington, DC: The Urban Institute.

Weichselbaumer, Doris, 2001. "Sexual Orientation Discrimination in Hiring", Linz Working paper No. 00-21.

Wheeless, Sara C., Robert E. Manson, Jill D. Kavee, Richard A. Riemer, and Timothy W. Elig (1997). Armed Forces 1996 Equal Opportunity Survey: Statistical Methodology Report (Report No. 97-025). Arlington, VA: Defense Manpower Data Center.

Williams, Jill Hunter, Louise F. Fitzgerald, and Fritz Drasgow, 1999. "The Effects of Organizational Practices on Sexual Harassment and Individual Outcomes in the Military", Military Psychology, 11(3), pp. 303-328. 
Table 1. Racial Harassment by Race

\begin{tabular}{lrrr}
\hline & Offense & Threat & Career \\
\hline Overall & 0.652 & 0.095 & 0.130 \\
& $(0.476)$ & $(0.293)$ & $(0.336)$ \\
\multirow{3}{*}{ White } & {$[18035]$} & {$[17297]$} & {$[17950]$} \\
& 0.609 & 0.080 & 0.076 \\
& $(0.488)$ & $(0.272)$ & $(0.266)$ \\
Black & {$[5209]$} & {$[4952]$} & {$[5178]$} \\
& 0.750 & 0.133 & 0.291 \\
& $(0.433)$ & $(0.339)$ & $(0.454)$ \\
Hispanic & {$[4451]$} & {$[4309]$} & {$[4441]$} \\
& 0.781 & 0.113 & 0.201 \\
& $(0.414)$ & $(0.317)$ & $(0.401)$ \\
Asian & {$[4771]$} & {$[4598]$} & {$[4751]$} \\
& 0.675 & 0.151 & 0.163 \\
& $(0.468)$ & $(0.358)$ & $(0.370)$ \\
& {$[3604]$} & {$[3438]$} & {$[3580]$}
\end{tabular}

Sampling weights used. Standard deviations in parentheses.

Sample size in brackets. 
Table 2. Determinants of Racial Harassment: Baseline Model (Probit Marginal Effects and Standard Errors)

\begin{tabular}{|c|c|c|c|}
\hline & \multicolumn{3}{|c|}{ Model 1} \\
\hline & Offense & Threat & Career \\
\hline \multicolumn{4}{|l|}{ Race } \\
\hline Black & $\begin{array}{l}0.126^{* * * *} \\
(0.013)\end{array}$ & $\begin{array}{l}0.041 * * * \\
(0.010)\end{array}$ & $\begin{array}{l}0.209 * * * \\
(0.012)\end{array}$ \\
\hline Hispanic & $\begin{array}{l}0.141 * * * \\
(0.014)\end{array}$ & $\begin{array}{l}0.016^{*} \\
(0.009)\end{array}$ & $\begin{array}{l}0.132 * * * \\
(0.014)\end{array}$ \\
\hline Asian & $\begin{array}{l}0.063 * * * \\
(0.016)\end{array}$ & $\begin{array}{l}0.069 * * * \\
(0.019)\end{array}$ & $\begin{array}{l}0.104 * * * \\
(0.017)\end{array}$ \\
\hline \multicolumn{4}{|c|}{ Demographic and Human Capital Characteristics (Xij) } \\
\hline Married & $\begin{array}{l}0.000 \\
(0.015)\end{array}$ & $\begin{array}{l}0.001 \\
(0.009)\end{array}$ & $\begin{array}{l}0.019 * * \\
(0.009)\end{array}$ \\
\hline \multicolumn{4}{|l|}{ Education } \\
\hline Some College & $\begin{array}{l}0.035 * * \\
(0.017)\end{array}$ & $\begin{array}{l}0.007 \\
(0.010)\end{array}$ & $\begin{array}{l}0.010 \\
(0.011)\end{array}$ \\
\hline College & $\begin{array}{l}-0.098 * * * \\
(0.019)\end{array}$ & $\begin{array}{l}-0.031 * * * \\
(0.010)\end{array}$ & $\begin{array}{l}-0.008 \\
(0.012)\end{array}$ \\
\hline Female & $\begin{array}{l}-0.077 * * * \\
(0.019)\end{array}$ & $\begin{array}{l}-0.020 * * \\
(0.010)\end{array}$ & $\begin{array}{l}0.009 \\
(0.012)\end{array}$ \\
\hline \multicolumn{4}{|c|}{ Years of Active Service } \\
\hline $7-11$ & $\begin{array}{l}-0.034^{*} \\
(0.020)\end{array}$ & $\begin{array}{l}-0.032 * * * \\
(0.010)\end{array}$ & $\begin{array}{l}-0.014 \\
(0.012)\end{array}$ \\
\hline $12-19$ & $\begin{array}{l}-0.076^{* * * *} \\
(0.017)\end{array}$ & $\begin{array}{l}-0.015 \\
(0.010)\end{array}$ & $\begin{array}{l}0.001 \\
(0.011)\end{array}$ \\
\hline $20+$ & $\begin{array}{l}-0.144 * * * \\
(0.023)\end{array}$ & $\begin{array}{l}-0.028 * * * \\
(0.010)\end{array}$ & $\begin{array}{l}-0.019 \\
(0.012)\end{array}$ \\
\hline \multicolumn{4}{|c|}{ Awareness of Racial Harassment Programs } \\
\hline Training & $\begin{array}{l}0.007 \\
(0.014)\end{array}$ & $\begin{array}{l}-0.008 \\
(0.008)\end{array}$ & $\begin{array}{l}-0.023 * * * \\
(0.009)\end{array}$ \\
\hline Hotlines & $\begin{array}{l}-0.062 * * * \\
(0.018)\end{array}$ & $\begin{array}{l}-0.025^{*} \\
(0.013)\end{array}$ & $\begin{array}{l}-0.060 * * * \\
(0.013)\end{array}$ \\
\hline Channels & $\begin{array}{l}-0.034^{*} \\
(0.019)\end{array}$ & $\begin{array}{l}-0.051 * * * \\
(0.014)\end{array}$ & $\begin{array}{l}-0.018 \\
(0.013)\end{array}$ \\
\hline Pseudo $\mathbf{R}^{2}$ & 0.046 & 0.051 & 0.097 \\
\hline
\end{tabular}

Sampling weights used. Number of observations are 18,035, 17,297, and 17,950 for offense, threat, and career, respectively. $* * *, * *$, and $*$ significant at the $1 \%, 5 \%$, and $10 \%$ level, respectively. Standard errors are adjusted for clustering by installation. 
Table 3. Determinants of Racial Harassment Including Controls for Organizational Identity Groups (Probit Marginal Effects and Standard Errors)

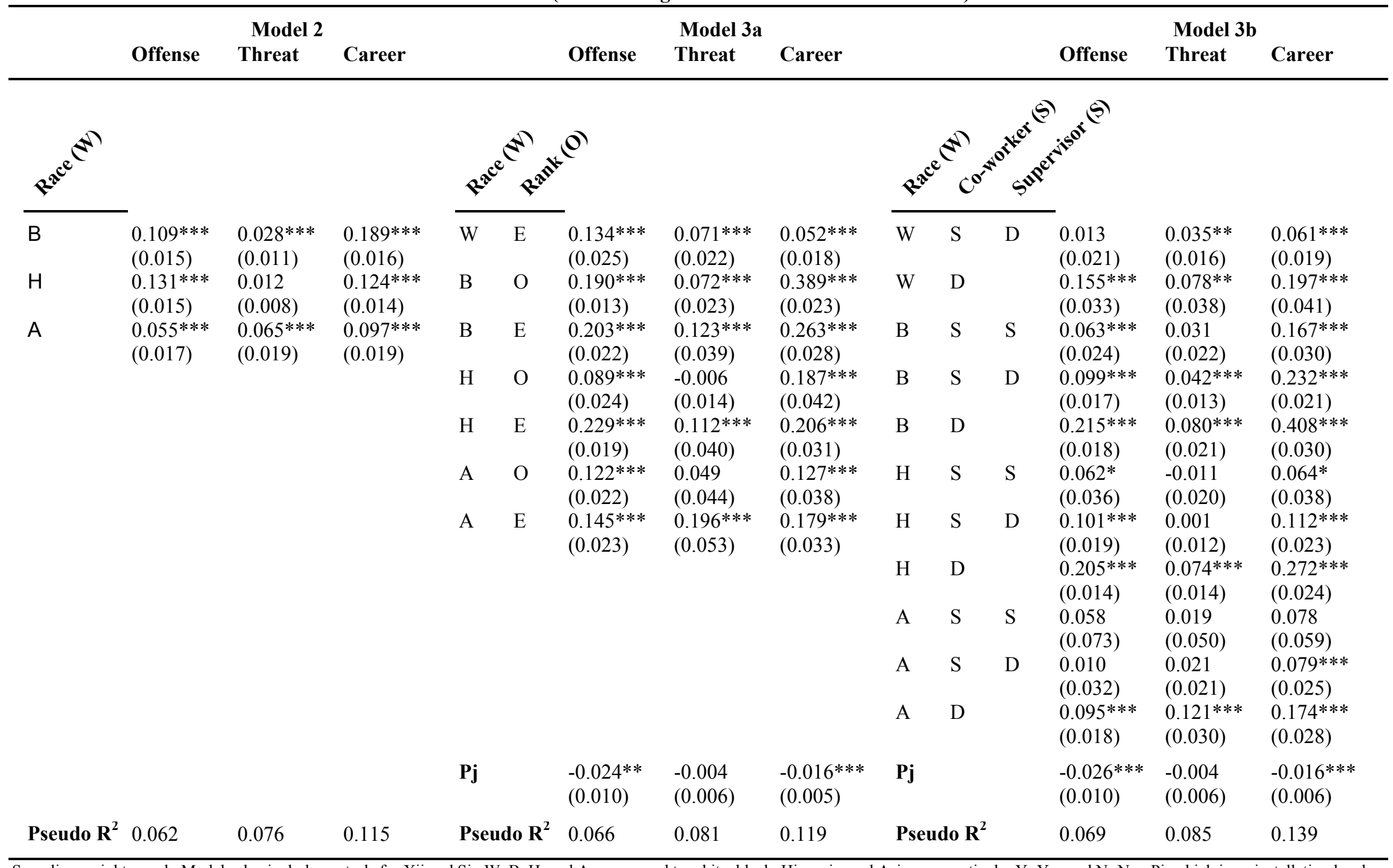

Sampling weights used. Models also include controls for Xij and Sj. W, B, H, and A correspond to white, black, Hispanic, and Asian, respectively. Y=Yes and N=No. Pj, which is an installation level mean index, represents social prescriptions about how races should behave. Number of observations are 18,035, 17,297, and 17,950 for offense, threat, and career, respectively. ***,**, and * significant at the $1 \%, 5 \%$, and $10 \%$ level, respectively. Standard errors are adjusted for clustering by installation. 
Table 4. Determinants of Racial Harassment Including Controls for Individual Identity Groups (Probit Marginal Effects and Standard Errors)

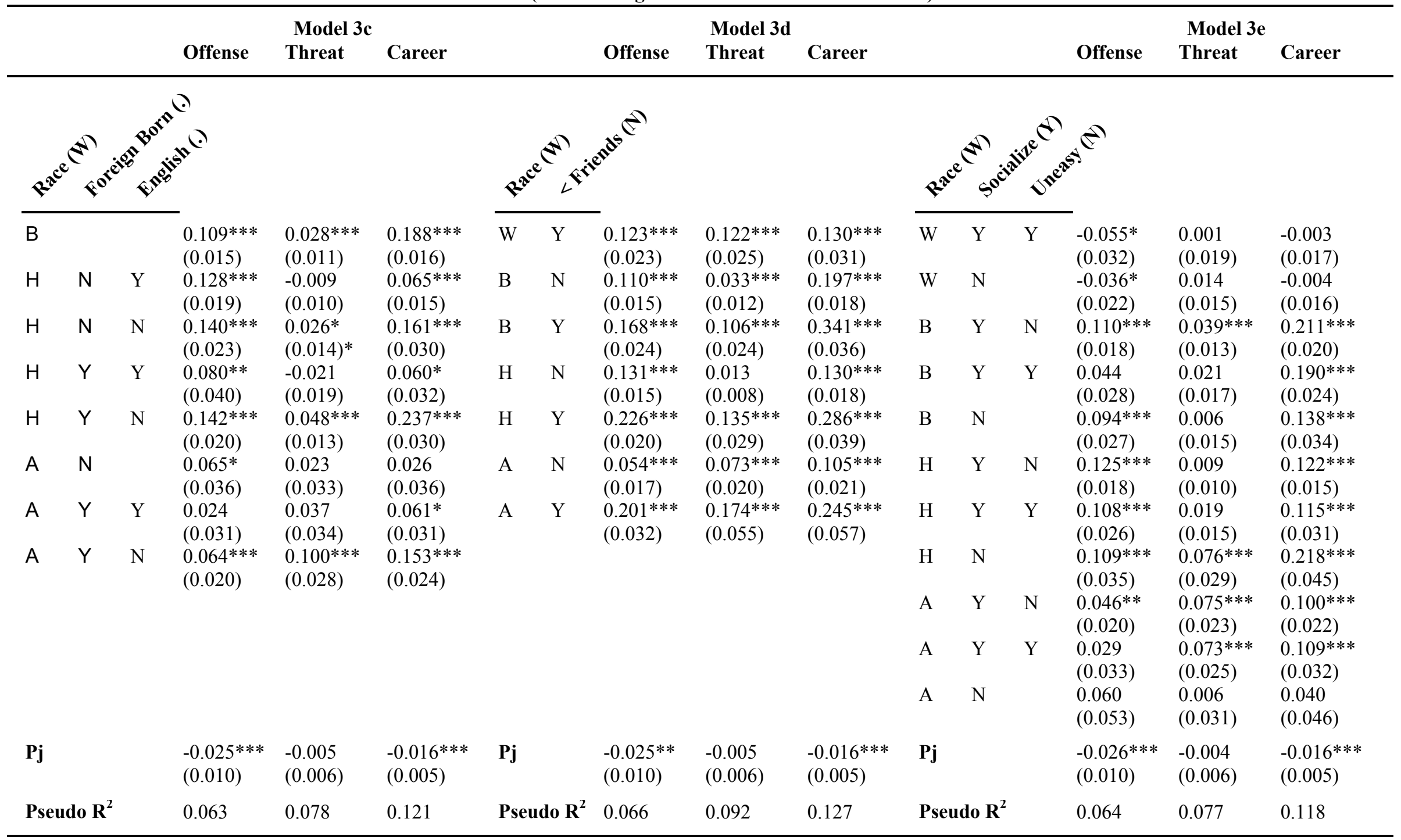

Sampling weights used. Models also include controls for Xij and $\mathrm{Sj}$. W, B, H, and A correspond to white, black, Hispanic, and Asian, respectively. Y=Yes and $\mathrm{N}=\mathrm{No}$. Pj, which is an installation level mean index, represents social prescriptions about how races should behave. Number of observations are $18,035,17,297$, and 17,950 for offense, threat, and career, respectively. $* * *, * *$, and * significant at the $1 \%, 5 \%$, and $10 \%$ level, respectively. Standard errors are adjusted for clustering by installation. 
Table 5. The Importance of Race versus Identity

(P-values)

\begin{tabular}{|c|c|c|c|c|c|c|c|c|c|c|c|}
\hline \multicolumn{12}{|c|}{ Panel A: Organizational Identity Groups } \\
\hline & \multirow[b]{2}{*}{ Offense } & \multicolumn{2}{|c|}{ Model 3a } & \multicolumn{4}{|c|}{ Model 3b } & & & & \\
\hline & & Threat & Career & \multicolumn{2}{|c|}{ Offense } & Threat & Career & & & & \\
\hline \multicolumn{4}{|c|}{ Within Race, Does Identity Matter? } & \multicolumn{4}{|c|}{ Within Race, Does Identity Matter? } & & & & \\
\hline White & 0.000 & 0.002 & 0.003 & White & 0.000 & 0.008 & 0.000 & & & & \\
\hline Black & 0.956 & 0.017 & 0.003 & Black & 0.000 & 0.110 & 0.000 & & & & \\
\hline Hispanic & 0.000 & 0.000 & 0.531 & Hispanic & 0.000 & 0.000 & 0.000 & & & & \\
\hline Asian & 0.431 & 0.020 & 0.213 & Asian & 0.027 & 0.008 & 0.019 & & & & \\
\hline \multicolumn{4}{|c|}{ Within Identity, Does Race Matter? } & \multicolumn{4}{|c|}{ Within Identity, Does Race Matter? } & & & & \\
\hline Enlisted & 0.000 & 0.006 & 0.000 & Common/Same & 0.034 & 0.412 & 0.000 & & & & \\
\hline \multirow[t]{2}{*}{ Officer } & \multirow[t]{2}{*}{0.000} & \multirow[t]{2}{*}{0.000} & \multirow[t]{2}{*}{0.000} & Common/Different & 0.000 & 0.020 & 0.000 & & & & \\
\hline & & & & Uncommon & 0.000 & 0.504 & 0.000 & & & & \\
\hline \multicolumn{12}{|c|}{ Panel B: Individual Identity Groups } \\
\hline & \multicolumn{3}{|c|}{ Model 3c } & \multicolumn{4}{|c|}{ Model 3d } & & \multicolumn{3}{|c|}{ Model 3e } \\
\hline & Offense & Threat & Career & \multicolumn{2}{|r|}{ Offense } & Threat & Career & & Offense & Threat & Career \\
\hline \multicolumn{4}{|c|}{ Within Race, Does Identity Matter? } & \multicolumn{4}{|c|}{ Within Race, Does Identity Matter? } & \multicolumn{4}{|c|}{ Within Race, Does Identity Matter? } \\
\hline Hispanic & 0.490 & 0.001 & 0.000 & White & 0.000 & 0.000 & 0.000 & White & 0.077 & 0.615 & 0.966 \\
\hline Asian & 0.530 & 0.150 & 0.009 & Black & 0.016 & 0.002 & 0.000 & Black & 0.111 & 0.097 & 0.004 \\
\hline & & & & Hispanic & 0.000 & 0.000 & 0.000 & Hispanic & 0.817 & 0.021 & 0.061 \\
\hline & & & & Asian & 0.000 & 0.043 & 0.010 & Asian & 0.829 & 0.210 & 0.425 \\
\hline \multicolumn{4}{|c|}{ Within Identity, Does Race Matter? } & \multicolumn{3}{|c|}{ Within Identity, Does Race Matter? } & & \multicolumn{4}{|c|}{ Within Identity, Does Race Matter? } \\
\hline Native/English & 0.000 & 0.016 & 0.000 & Fewer Friends & 0.005 & 0.582 & 0.000 & Social/Easy & 0.000 & 0.000 & 0.000 \\
\hline Foreign/English & 0.278 & 0.126 & 0.985 & Same/More Friends & 0.000 & 0.000 & 0.000 & Social/Uneasy & 0.000 & 0.096 & 0.000 \\
\hline Foreign/Not English & 0.001 & 0.068 & 0.015 & & & & & Not Social & 0.000 & 0.078 & 0.000 \\
\hline
\end{tabular}

Based on results presented in Tables 3 and 4. 
Table 6. Determinants of Racial Harassment--Institutional Factors (Probit Marginal Effects and Standard Errors)

\begin{tabular}{|c|c|c|c|c|c|c|c|c|c|}
\hline & \multicolumn{3}{|c|}{ Model 2} & \multicolumn{3}{|c|}{ Model 3a } & \multicolumn{3}{|c|}{ Model 3b } \\
\hline & Offense & Threat & Career & Offense & Threat & Career & Offense & Threat & Career \\
\hline \multicolumn{10}{|l|}{ Service } \\
\hline Navy & $\begin{array}{l}-0.003 \\
(0.019)\end{array}$ & $\begin{array}{l}-0.010 \\
(0.010)\end{array}$ & $\begin{array}{l}-0.013 \\
(0.010)\end{array}$ & $\begin{array}{l}-0.002 \\
(0.019)\end{array}$ & $\begin{array}{l}-0.011 \\
(0.010)\end{array}$ & $\begin{array}{l}-0.011 \\
(0.009)\end{array}$ & $\begin{array}{l}-0.003 \\
(0.019)\end{array}$ & $\begin{array}{l}-0.008 \\
(0.011)\end{array}$ & $\begin{array}{l}-0.012 \\
(0.010)\end{array}$ \\
\hline Marines & $\begin{array}{l}0.033 \\
(0.022)\end{array}$ & $\begin{array}{l}-0.003 \\
(0.011)\end{array}$ & $\begin{array}{l}-0.024 * * \\
(0.010)\end{array}$ & $\begin{array}{l}0.031 \\
(0.024)\end{array}$ & $\begin{array}{l}-0.004 \\
(0.010)\end{array}$ & $\begin{array}{l}-0.025^{* *} \\
(0.010)\end{array}$ & $\begin{array}{l}0.030 \\
(0.025)\end{array}$ & $\begin{array}{l}-0.001 \\
(0.011)\end{array}$ & $\begin{array}{l}-0.023 * * \\
(0.009)\end{array}$ \\
\hline Air Force & $\begin{array}{l}-0.044 * * \\
(0.021)\end{array}$ & $\begin{array}{l}-0.030 * * * \\
(0.008)\end{array}$ & $\begin{array}{l}-0.051 * * * \\
(0.010)\end{array}$ & $\begin{array}{l}-0.038^{*} \\
(0.021)\end{array}$ & $\begin{array}{l}-0.030^{* * *} \\
(0.009)\end{array}$ & $\begin{array}{l}-0.046^{* * *} \\
(0.010)\end{array}$ & $\begin{array}{l}-0.034 \\
(0.021)\end{array}$ & $\begin{array}{l}-0.026^{* * *} \\
(0.009)\end{array}$ & $\begin{array}{l}-0.044 * * * \\
(0.010)\end{array}$ \\
\hline \multicolumn{10}{|c|}{ Installation Level Mean Characteristics } \\
\hline Racial Confrontation & $\begin{array}{l}0.364 * * * \\
(0.088)\end{array}$ & $\begin{array}{l}0.122 * * * \\
(0.035)\end{array}$ & $\begin{array}{l}0.074 \\
(0.049)\end{array}$ & $\begin{array}{l}0.307 * * * \\
(0.089)\end{array}$ & $\begin{array}{l}0.106^{* * * *} \\
(0.038)\end{array}$ & $\begin{array}{l}0.033 \\
(0.050)\end{array}$ & $\begin{array}{l}0.299 * * * \\
(0.087)\end{array}$ & $\begin{array}{l}0.110^{* * *} \\
(0.038)\end{array}$ & $\begin{array}{l}0.028 \\
(0.052)\end{array}$ \\
\hline $\begin{array}{c}\text { Reports of Harassment } \\
\text { w/o Repercussions }\end{array}$ & $\begin{array}{l}-0.024 \\
(0.096)\end{array}$ & $\begin{array}{l}0.042 \\
(0.056)\end{array}$ & $\begin{array}{l}-0.069 \\
(0.050)\end{array}$ & $\begin{array}{l}-0.038 \\
(0.096)\end{array}$ & $\begin{array}{l}0.038 \\
(0.057)\end{array}$ & $\begin{array}{l}-0.081 \\
(0.049)\end{array}$ & $\begin{array}{l}-0.043 \\
(0.096)\end{array}$ & $\begin{array}{l}0.039 \\
(0.056)\end{array}$ & $\begin{array}{l}-0.065 \\
(0.051)\end{array}$ \\
\hline Racial Relations Good & $\begin{array}{l}0.046 \\
(0.094)\end{array}$ & $\begin{array}{l}0.001 \\
(0.060)\end{array}$ & $\begin{array}{l}0.123 * * \\
(0.050)\end{array}$ & $\begin{array}{l}0.056 \\
(0.096)\end{array}$ & $\begin{array}{l}0.003 \\
(0.061)\end{array}$ & $\begin{array}{l}0.134 * * * \\
(0.051)\end{array}$ & $\begin{array}{l}0.064 \\
(0.094)\end{array}$ & $\begin{array}{l}0.007 \\
(0.060)\end{array}$ & $\begin{array}{l}0.124 * * \\
(0.055)\end{array}$ \\
\hline Hotlines & $\begin{array}{l}0.078 \\
(0.077)\end{array}$ & $\begin{array}{l}0.047 \\
(0.039)\end{array}$ & $\begin{array}{l}0.056 \\
(0.041)\end{array}$ & $\begin{array}{l}0.082 \\
(0.076)\end{array}$ & $\begin{array}{l}0.050 \\
(0.041)\end{array}$ & $\begin{array}{l}0.065 \\
(0.041)\end{array}$ & $\begin{array}{l}0.071 \\
(0.076)\end{array}$ & $\begin{array}{l}0.051 \\
(0.040)\end{array}$ & $\begin{array}{l}0.059 \\
(0.041)\end{array}$ \\
\hline Channels & $\begin{array}{l}0.035 \\
(0.083)\end{array}$ & $\begin{array}{l}-0.048 \\
(0.045)\end{array}$ & $\begin{array}{l}-0.050 \\
(0.048)\end{array}$ & $\begin{array}{l}0.081 \\
(0.079)\end{array}$ & $\begin{array}{l}-0.037 \\
(0.044)\end{array}$ & $\begin{array}{l}-0.026 \\
(0.047)\end{array}$ & $\begin{array}{l}0.062 \\
(0.079)\end{array}$ & $\begin{array}{l}-0.048 \\
(0.043)\end{array}$ & $\begin{array}{l}-0.033 \\
(0.048)\end{array}$ \\
\hline \multirow[t]{2}{*}{ Percent White } & $\begin{array}{l}-0.197 * * \\
(0.092)\end{array}$ & $\begin{array}{l}-0.135^{* * *} \\
(0.042)\end{array}$ & $\begin{array}{l}-0.117^{* *} \\
(0.053)\end{array}$ & $\begin{array}{l}-0.125 \\
(0.098)\end{array}$ & $\begin{array}{l}-0.120^{* * *} \\
(0.044)\end{array}$ & $\begin{array}{l}-0.071 \\
(0.055)\end{array}$ & $\begin{array}{l}-0.113 \\
(0.098)\end{array}$ & $\begin{array}{l}-0.116^{* * *} \\
(0.043)\end{array}$ & $\begin{array}{l}-0.060 \\
(0.055)\end{array}$ \\
\hline & Offense & \multicolumn{2}{|c|}{ Model 3c } & Offense & $\begin{array}{l}\text { Model 3d } \\
\text { Threat }\end{array}$ & Career & Offense & $\begin{array}{l}\text { Model 3e } \\
\text { Threat }\end{array}$ & Career \\
\hline \multicolumn{10}{|l|}{ Service } \\
\hline Navy & $\begin{array}{l}0.000 \\
(0.019)\end{array}$ & $\begin{array}{l}-0.009 \\
(0.010)\end{array}$ & $\begin{array}{l}-0.010 \\
(0.010)\end{array}$ & $\begin{array}{l}0.000 \\
(0.019)\end{array}$ & $\begin{array}{l}-0.008 \\
(0.010)\end{array}$ & $\begin{array}{l}-0.010 \\
(0.009)\end{array}$ & $\begin{array}{l}0.000 \\
(0.019)\end{array}$ & $\begin{array}{l}-0.010 \\
(0.010)\end{array}$ & $\begin{array}{l}-0.011 \\
(0.010)\end{array}$ \\
\hline Marines & $\begin{array}{l}0.032 \\
(0.024)\end{array}$ & $\begin{array}{l}-0.003 \\
(0.011)\end{array}$ & $\begin{array}{l}-0.023 * * \\
(0.010)\end{array}$ & $\begin{array}{l}0.033 \\
(0.023)\end{array}$ & $\begin{array}{l}-0.001 \\
(0.011)\end{array}$ & $\begin{array}{l}-0.024 * * \\
(0.010)\end{array}$ & $\begin{array}{l}0.029 \\
(0.024)\end{array}$ & $\begin{array}{l}-0.003 \\
(0.011)\end{array}$ & $\begin{array}{l}-0.025 * * \\
(0.010)\end{array}$ \\
\hline Air Force & $\begin{array}{l}-0.031 \\
(0.020)\end{array}$ & $\begin{array}{l}-0.027 * * * \\
(0.009)\end{array}$ & $\begin{array}{l}-0.043 * * * \\
(0.010)\end{array}$ & $\begin{array}{l}-0.031 \\
(0.020)\end{array}$ & $\begin{array}{l}-0.027 * * * \\
(0.009)\end{array}$ & $\begin{array}{l}-0.045^{* * *} \\
(0.010)\end{array}$ & $\begin{array}{l}-0.031 \\
(0.021)\end{array}$ & $\begin{array}{l}-0.029 * * * \\
(0.009)\end{array}$ & $\begin{array}{l}-0.046^{* * *} \\
(0.010)\end{array}$ \\
\hline \multicolumn{10}{|c|}{ Installation Level Mean Characteristics } \\
\hline Racial Confrontation & $\begin{array}{l}0.307 * * * \\
(0.089)\end{array}$ & $\begin{array}{l}0.108 * * * \\
(0.038)\end{array}$ & $\begin{array}{l}0.030 \\
(0.051)\end{array}$ & $\begin{array}{l}0.301 * * * \\
(0.091)\end{array}$ & $\begin{array}{l}0.101 * * * \\
(0.038)\end{array}$ & $\begin{array}{l}0.022 \\
(0.048)\end{array}$ & $\begin{array}{l}0.300^{* * *} \\
(0.090)\end{array}$ & $\begin{array}{l}0.113 * * * \\
(0.038)\end{array}$ & $\begin{array}{l}0.032 \\
(0.051)\end{array}$ \\
\hline $\begin{array}{l}\text { Reports of Harassment } \\
\text { w/o Repercussions }\end{array}$ & $\begin{array}{l}-0.039 \\
(0.096)\end{array}$ & $\begin{array}{l}0.039 \\
(0.057)\end{array}$ & $\begin{array}{l}-0.080 \\
(0.050)\end{array}$ & $\begin{array}{l}-0.030 \\
(0.097)\end{array}$ & $\begin{array}{l}0.041 \\
(0.059)\end{array}$ & $\begin{array}{l}-0.082 * \\
(0.049)\end{array}$ & $\begin{array}{l}-0.033 \\
(0.096)\end{array}$ & $\begin{array}{l}0.040 \\
(0.058)\end{array}$ & $\begin{array}{l}-0.078 \\
(0.050)\end{array}$ \\
\hline Racial Relations Good & $\begin{array}{l}0.062 \\
(0.096)\end{array}$ & $\begin{array}{l}0.005 \\
(0.061)\end{array}$ & $\begin{array}{l}0.135^{* *} \\
(0.052)\end{array}$ & $\begin{array}{l}0.053 \\
(0.098)\end{array}$ & $\begin{array}{l}0.008 \\
(0.063)\end{array}$ & $\begin{array}{l}0.136 * * * \\
(0.051)\end{array}$ & $\begin{array}{l}0.053 \\
(0.098)\end{array}$ & $\begin{array}{l}0.006 \\
(0.062)\end{array}$ & $\begin{array}{l}0.132 * * \\
(0.052)\end{array}$ \\
\hline Hotlines & $\begin{array}{l}0.087 \\
(0.076)\end{array}$ & $\begin{array}{l}0.051 \\
(0.040)\end{array}$ & $\begin{array}{l}0.068 \\
(0.041)\end{array}$ & $\begin{array}{l}0.085 \\
(0.076)\end{array}$ & $\begin{array}{l}0.049 \\
(0.040)\end{array}$ & $\begin{array}{l}0.070^{*} \\
(0.041)\end{array}$ & $\begin{array}{l}0.088 \\
(0.076)\end{array}$ & $\begin{array}{l}0.052 \\
(0.040)\end{array}$ & $\begin{array}{l}0.070^{*} \\
(0.042)\end{array}$ \\
\hline Channels & $\begin{array}{l}0.067 \\
(0.080)\end{array}$ & $\begin{array}{l}-0.043 \\
(0.045)\end{array}$ & $\begin{array}{l}-0.027 \\
(0.048)\end{array}$ & $\begin{array}{l}0.073 \\
(0.080)\end{array}$ & $\begin{array}{l}-0.043 \\
(0.046)\end{array}$ & $\begin{array}{l}-0.032 \\
(0.045)\end{array}$ & $\begin{array}{l}0.068 \\
(0.080)\end{array}$ & $\begin{array}{l}-0.045 \\
(0.045)\end{array}$ & $\begin{array}{l}-0.029 \\
(0.048)\end{array}$ \\
\hline Percent White & $\begin{array}{l}-0.126 \\
(0.099)\end{array}$ & $\begin{array}{l}-0.122 * * * \\
(0.044)\end{array}$ & $\begin{array}{l}-0.076 \\
(0.055)\end{array}$ & $\begin{array}{l}-0.138 \\
(0.099)\end{array}$ & $\begin{array}{l}-0.121^{* * *} \\
(0.045)\end{array}$ & $\begin{array}{l}-0.076 \\
(0.054)\end{array}$ & $\begin{array}{l}-0.132 \\
(0.100)\end{array}$ & $\begin{array}{l}-0.119^{* * *} \\
(0.044)\end{array}$ & $\begin{array}{l}-0.074 \\
(0.055)\end{array}$ \\
\hline
\end{tabular}




\section{Offensive Encounters}

Unwelcome Attempts To Discuss Race/Ethnicity

Told Racist Stories/Jokes

Condescending Due To Race/Ethnicity

Distribute Racist Materials

Displayed Racist Tattoos/Clothing

Not Included In Activity Due To Race/Ethnicity

Uncomfortable, Hostile Looks/Stares Due to Race/Ethnicity

Offensive Remarks About Appearance Due to Race/Ethnicity

Remarks Your Race/Ethnicity Not Suited To Job

\section{Threat/Harm}

Offensive Remarks About Race/Ethnicity

Vandalized Property Due To Race/Ethnicity

Threatened With Retaliation if Did Not Partake in Racist Behavior

Physically Threatened/Intimidated Due to Race/Ethnicity

Career*

Assaulted You Physically Due to Race/Ethnicity

\section{Assignment/Career}

Assignment Has Not Made Use Of Job Skills

Current Assignment Not Good For Career

No Short Term Tasks To Prepare For Advancement

No Professional Relationship For Career Development Advice

Learned Of Opportunities Too Late For Career

No Straight Answers For Promotion Possibilities

Excluded by Peers From Social Activities

\section{Evaluation}

Rated Lower Than Deserved On Last Evaluation

Last Evaluation Contained Unjustified Comments

Held To Higher Performance Standards Than Others

Didn't Receive Award Like Others

\section{Punishment}

Wrongly Taken To Non-Judical Punishment

Punished When Others Were Not

\section{Training/Test Scores}

Unable To Attend Major School Necessary For Job

Unable To Attend Short Courses Necessary For Job

Received Lower Grades Than Deserved

Didn't Get Job Due To Scores On Test

\footnotetext{
*Coded as 1 if respondent answered yes and his/her race was a factor, zero otherwise.
} 
Appendix Table 2. Sample Means by Race

\begin{tabular}{|c|c|c|c|c|c|c|c|c|c|c|}
\hline & \multicolumn{2}{|c|}{ Total } & \multicolumn{2}{|c|}{ White } & \multicolumn{2}{|c|}{ Black } & \multicolumn{2}{|c|}{ Hispanic } & \multicolumn{2}{|c|}{ Asian } \\
\hline & Mean & St. Dev. & Mean & St. Dev. & Mean & St. Dev. & Mean & St. Dev. & Mean & St. Dev. \\
\hline \multicolumn{11}{|l|}{ Social Categories (Gij) } \\
\hline Officer & 0.193 & 0.394 & 0.235 & 0.424 & 0.081 & 0.272 & 0.096 & 0.294 & 0.190 & 0.393 \\
\hline Common/Same & 0.557 & 0.497 & 0.720 & 0.449 & 0.258 & 0.438 & 0.065 & 0.246 & 0.057 & 0.232 \\
\hline Common/Different & 0.319 & 0.466 & 0.234 & 0.424 & 0.532 & 0.499 & 0.546 & 0.498 & 0.313 & 0.464 \\
\hline Uncommon & 0.124 & 0.330 & 0.046 & 0.210 & 0.210 & 0.408 & 0.389 & 0.488 & 0.629 & 0.483 \\
\hline Native/English & 0.903 & 0.296 & 0.970 & 0.172 & 0.942 & 0.234 & 0.518 & 0.500 & 0.260 & 0.439 \\
\hline Native/Not English & 0.017 & 0.131 & 0.004 & 0.063 & 0.007 & 0.082 & 0.145 & 0.352 & 0.016 & 0.125 \\
\hline Foreign Born/English & 0.035 & 0.185 & 0.022 & 0.147 & 0.048 & 0.214 & 0.055 & 0.228 & 0.200 & 0.400 \\
\hline Foreign Born/Not English & 0.045 & 0.206 & 0.004 & 0.065 & 0.003 & 0.058 & 0.282 & 0.450 & 0.524 & 0.499 \\
\hline Same/More Friends & 0.911 & 0.285 & 0.920 & 0.271 & 0.882 & 0.323 & 0.896 & 0.305 & 0.924 & 0.266 \\
\hline Social/Easy & 0.706 & 0.455 & 0.706 & 0.456 & 0.685 & 0.465 & 0.739 & 0.439 & 0.750 & 0.433 \\
\hline Social/Uneasy & 0.138 & 0.345 & 0.114 & 0.318 & 0.193 & 0.395 & 0.203 & 0.402 & 0.182 & 0.386 \\
\hline Not Social & 0.155 & 0.362 & 0.180 & 0.384 & 0.122 & 0.328 & 0.058 & 0.233 & 0.068 & 0.252 \\
\hline \multicolumn{11}{|c|}{ Demographic and Human Capital Characteristics (Xij) } \\
\hline Married & 0.662 & 0.473 & 0.683 & 0.465 & 0.625 & 0.484 & 0.615 & 0.487 & 0.557 & 0.497 \\
\hline \multicolumn{11}{|l|}{ Education } \\
\hline High School & 0.263 & 0.441 & 0.250 & 0.433 & 0.281 & 0.449 & 0.343 & 0.475 & 0.224 & 0.417 \\
\hline Some College & 0.507 & 0.500 & 0.482 & 0.500 & 0.599 & 0.490 & 0.525 & 0.499 & 0.484 & 0.500 \\
\hline College & 0.229 & 0.420 & 0.268 & 0.443 & 0.120 & 0.325 & 0.132 & 0.338 & 0.292 & 0.455 \\
\hline Female & 0.143 & 0.350 & 0.121 & 0.326 & 0.236 & 0.425 & 0.114 & 0.318 & 0.153 & 0.360 \\
\hline \multicolumn{11}{|l|}{ Years of Active Service } \\
\hline$<6$ & 0.446 & 0.497 & 0.446 & 0.497 & 0.394 & 0.489 & 0.547 & 0.498 & 0.463 & 0.499 \\
\hline $7-11$ & 0.181 & 0.385 & 0.179 & 0.384 & 0.194 & 0.395 & 0.158 & 0.365 & 0.192 & 0.394 \\
\hline $12-19$ & 0.297 & 0.457 & 0.295 & 0.456 & 0.336 & 0.472 & 0.242 & 0.428 & 0.263 & 0.440 \\
\hline $20+$ & 0.077 & 0.266 & 0.079 & 0.271 & 0.077 & 0.266 & 0.053 & 0.224 & 0.082 & 0.274 \\
\hline \multicolumn{11}{|l|}{ Awareness of Racial Harassment Programs } \\
\hline Training & 0.655 & 0.475 & 0.681 & 0.466 & 0.583 & 0.493 & 0.611 & 0.488 & 0.615 & 0.487 \\
\hline Hotlines & 0.565 & 0.496 & 0.592 & 0.491 & 0.504 & 0.500 & 0.484 & 0.500 & 0.550 & 0.498 \\
\hline Channels & 0.625 & 0.484 & 0.662 & 0.473 & 0.540 & 0.498 & 0.528 & 0.499 & 0.585 & 0.493 \\
\hline \multicolumn{11}{|l|}{ Institutional Factors (Sj) } \\
\hline \multicolumn{11}{|l|}{ Service } \\
\hline Army & 0.346 & 0.476 & 0.306 & 0.461 & 0.494 & 0.500 & 0.377 & 0.485 & 0.274 & 0.446 \\
\hline Navy & 0.203 & 0.402 & 0.208 & 0.406 & 0.164 & 0.370 & 0.191 & 0.393 & 0.373 & 0.484 \\
\hline Marines & 0.129 & 0.335 & 0.130 & 0.337 & 0.103 & 0.304 & 0.192 & 0.394 & 0.077 & 0.267 \\
\hline Air Force & 0.321 & 0.467 & 0.355 & 0.479 & 0.239 & 0.427 & 0.240 & 0.427 & 0.277 & 0.447 \\
\hline \multicolumn{11}{|l|}{ Installation Level Mean Characteristics } \\
\hline Military Confrontation & 0.296 & 0.127 & & & & & & & & \\
\hline Hotlines & 0.559 & 0.112 & & & & & & & & \\
\hline Channels & 0.618 & 0.113 & & & & & & & & \\
\hline Percent White & 0.678 & 0.112 & & & & & & & & \\
\hline Reports of Harassment without Repurcussions & 0.626 & 0.095 & & & & & & & & \\
\hline Racial Relations Good & 0.664 & 0.118 & & & & & & & & \\
\hline \multicolumn{11}{|l|}{ Social Prescriptions $(\mathbf{P j})$} \\
\hline Installation Level Mean Index & 19.712 & 1.014 & & & & & & & & \\
\hline
\end{tabular}

Sampling weights used. Number of observations are 18,035 5,209, 4,451, 4,771, and 3,604 for the total, white, black, Hispanic, and Asian samples, respectively. 
Appendix Table 3. Effects of Racial Harassment by Race

\begin{tabular}{|c|c|c|c|c|c|c|c|c|c|c|}
\hline & \multicolumn{2}{|c|}{ Total } & \multicolumn{2}{|c|}{ White } & \multicolumn{2}{|c|}{ Black } & \multicolumn{2}{|c|}{ Hispanic } & \multicolumn{2}{|c|}{ Asian } \\
\hline & Mean & Std. Dev. & Mean & Std. Dev. & Mean & Std. Dev. & Mean & Std. Dev. & Mean & Std. Dev. \\
\hline Lost Time From Work & 0.046 & 0.208 & 0.037 & 0.189 & 0.059 & 0.235 & 0.058 & 0.235 & 0.072 & 0.259 \\
\hline Decreased Productivity & 0.210 & 0.407 & 0.185 & 0.389 & 0.257 & 0.437 & 0.228 & 0.420 & 0.277 & 0.448 \\
\hline Lost Trust in Co-Workers & 0.368 & 0.482 & 0.318 & 0.466 & 0.468 & 0.499 & 0.428 & 0.495 & 0.435 & 0.496 \\
\hline Lost Trust in Supervisors & 0.356 & 0.479 & 0.287 & 0.452 & 0.512 & 0.500 & 0.408 & 0.491 & 0.394 & 0.489 \\
\hline Thoughts about Leaving Service & 0.356 & 0.479 & 0.314 & 0.464 & 0.456 & 0.498 & 0.382 & 0.486 & 0.357 & 0.479 \\
\hline Physical Ailments & 0.171 & 0.376 & 0.130 & 0.337 & 0.256 & 0.436 & 0.208 & 0.406 & 0.213 & 0.409 \\
\hline Sadness or Depression & 0.237 & 0.425 & 0.201 & 0.401 & 0.303 & 0.460 & 0.278 & 0.448 & 0.313 & 0.464 \\
\hline Anger or Rage & 0.558 & 0.497 & 0.526 & 0.499 & 0.639 & 0.480 & 0.570 & 0.495 & 0.564 & 0.496 \\
\hline Stress, Anxiety, or Fear & 0.327 & 0.469 & 0.312 & 0.463 & 0.365 & 0.482 & 0.312 & 0.463 & 0.381 & 0.486 \\
\hline Low Self-Esteem & 0.128 & 0.335 & 0.113 & 0.317 & 0.133 & 0.339 & 0.164 & 0.371 & 0.274 & 0.446 \\
\hline Thoughts of Suicide & 0.017 & 0.127 & 0.012 & 0.110 & 0.022 & 0.146 & 0.029 & 0.168 & 0.018 & 0.133 \\
\hline Thoughts of Harming Harasser & 0.252 & 0.434 & 0.227 & 0.419 & 0.296 & 0.456 & 0.299 & 0.458 & 0.257 & 0.437 \\
\hline At Least One of the Above & 0.750 & 0.433 & 0.716 & 0.451 & 0.832 & 0.374 & 0.760 & 0.427 & 0.767 & 0.423 \\
\hline Number of Observations & \multicolumn{2}{|c|}{$10423-10456$} & \multicolumn{2}{|c|}{$2395-2405$} & \multicolumn{2}{|c|}{$3057-3076$} & \multicolumn{2}{|c|}{$2916-2936$} & \multicolumn{2}{|c|}{$2044-2053$} \\
\hline
\end{tabular}

Sampling weights used. Sample only includes respondents who reported an incident of racial harassment and responded to these questions. 